\title{
Suplement do suplementu. Odpowiedź na Zbigniewa Anusika recenzję książki Wiśniowieccy. Monografia rodu
}

\author{
STRESZCZENIE:
}

Artykuł jest polemiką z poglądami Zbigniewa Anusika, zawartymi w jego artykule recenzyjnym dotyczącym książki Wiśniowieccy. Monografia rodu (Poznań 2007). Polemika dotyczy przede wszystkim takich zagadnień, jak: 1. Pisownia nazw i nazwisk z doby staropolskiej. 2. Pochodzenie i data urodzin Dymitra Wiśniowieckiego (starszego), a także pochodzenie jego niewątpliwej matki (3 dowody źródłowe) Marii Magdaleny Branković. 3. Działalność polityczna i militarna Dymitra Wiśniowieckiego (zamek Wiśniowieckiego na Chortycy nie był tożsamy z Siczą Zaporoska, wyjazd Wiśniowieckiego do Turcji był związany niewątpliwie ze sprawami mołdawskimi). 4. Pochodzenie Rainy Mohylanki i sprawa Uścia (przebieg procesu wygranego przez Annę Mohylankę). 5. Nadanie Chortycy Jeremiemu Wiśniowieckiemu. 6. Rzekome ojcostwo Dymitra Wiśniowieckiego (młodszego) wobec najstarszego syna Katarzyny Sobieskiej - Aleksandra Zasławskiego. 7. Relacja między Anną Dolską a Iwanem Mazepą. 8. Sprawa dóbr Borklo w Holandii, które nie mogły zostać sprzedane przez Teklę Różę Wiśniowiecka, choćby ze względu na nieuregulowany status własnościowy. Artykuł dotyczy też wielu innych kwestii związanych $\mathrm{z}$ rodziną Wiśniowieckich.

Słowa kluczowe: Wiśniowieccy, Maria Magdalena Branković, Chortyca, Sicz Zaporoska, Iwan Mazepa, Borklo

W roku 2009 na łamach łódzkiego czasopisma „Przegląd Nauk Historycznych" ukazał się obszerny artykuł recenzyjny dotyczący napisanej przeze mnie monografii o Wiśniowieckich ${ }^{1}$ autorstwa Zbigniewa Anusika, zatytułowany O książętach Wiśniowieckich i czasach, w których żyli. Suplement

${ }^{1}$ I. Czamańska, Wiśniowieccy. Monografia rodu, Wydawnictwo Poznańskie, Poznań 2007. 
do monografii rodu $u^{2}$. Autor recenzji postawił sobie za cel wyszukanie jak największej liczby uchybień wszelkiego rodzaju: pomyłek merytorycznych, nieszczęśliwych sformułowań, po błędy literowe. Część z tych uwag jest słuszna, uzupełnia materiał zaprezentowany w książce i koryguje pomyłki. Wypada więc w tym miejscu podziękować prof. Zbigniewowi Anusikowi za mimowolne sporządzenie bardzo szczegółowej recenzji wydawniczej, która przyda się do przygotowania drugiego wydania ${ }^{3}$.

Zakończyłoby się zapewne na tym podziękowaniu, gdyby nie fakt, że rozpowszechniona również $\mathrm{w}$ Internecie $\mathrm{e}^{4}$ i przedrukowana $\mathrm{w}$ zbiorze tegoż Autora Studia i szkice staropolskie ${ }^{5}$ recenzja w sposób bardzo sugestywny wypacza szereg moich poglądów jak też wprowadza liczne „korekty”, nie licząc się zupełnie $\mathrm{z}$ materiałem źródłowym zarówno zaprezentowanym w książce, jak też niedotyczącym bezpośrednio Wiśniowieckich i w pracy niewspomnianym. Milczenie $\mathrm{w}$ tej sprawie oznaczałoby cichą zgodę na rozpowszechnienie głoszonych ex catedra tez opartych na „wiedzy pozaźródłowej” kosztem badania materiału dokumentowego, który mniej lub bardziej trudny do interpretacji, musi być jednak podstawą naszych wnioskowań. Poważne zastrzeżenia budzi też forma recenzji (zwłaszcza pierwszej jej wersji), zawierająca liczne insynuacje ad personam. Nie chciałabym posądzać Recenzenta o złą wolę, jednak czytając tę recenzję trudno oprzeć się takiemu wrażeniu.

Liczne zarzuty postawione przez Recenzenta uważam za niesłuszne, nieuzasadnione, wyolbrzymione, a często nawet... zmanipulowane, o czym niżej.

Najpoważniejszym zarzutem pojawiającym się najczęściej są rzekome błędy w nazwach i nazwiskach, co w istocie przekłada się na żądanie ich polonizacji. Trudno się z tym zgodzić. Nie ma żadnego jasnego kryterium, które pozwoliłoby określić, jaka nazwa miejscowości jest właściwa na terenie, na którym dziś obowiązują nazwy ukraińskie, białoruskie i litewskie. Nazwy poszczególnych miejscowości i majętności ulegały zmianom, różnie były zapisywane w różnych okresach i różnych dokumen-

${ }^{2}$ Z. Anusik, O ksiażęetach Wiśniowieckich i czasach, w których żyli. Suplement do monografii rodu, „Przegląd Nauk Historycznych” 2009, t. 8, nr 2, s. 149-245. Strony odnotowane w tekście odnoszą się do tej publikacji.

${ }^{3}$ Niniejszy tekst miał zostać opublikowany jako dodatek do drugiego wydania monografii o Wiśniowieckich. Ponieważ jednak publikacja przeciąga się, a coraz częściej tekst Suplementu jest traktowany jak podstawowe źródło wiedzy na temat napisanej przeze mnie monografii, bez sięgania do oryginalnego tekstu, zdecydowałam się opublikować go, nie czekając na ukazanie się drugiego wydania.

${ }^{4}$ http://przeglad.uni.lodz.pl/t/2009nr2/za.pdf (dostęp: 10 XI 2015 r.).

${ }^{5}$ Z. Anusik, Studia i szkice staropolskie, Łódź 2011, s. 586-682. Tu pod tytułem Książęta Wiśniowieccy na tle swoich czasów. 
tach. (Oczywiście mogło się też czasem zdarzyć niedokładne odczytanie nazwy, nie da się tego całkowicie uniknąć, pracując głównie na rękopisach.) Majętności mogły też w różnym czasie mieć inną przynależność administracyjną i różne granice. Niektóre miejscowości odbudowywano po okresach nieistnienia. Którą więc nazwę uznać za właściwa, tę z XV, XVI, XVII, XVIII czy początku XX wieku? Czy można stosować nazwy, które nigdy nie występują $\mathrm{w}$ dokumentach, jak np. proponowane przez Zbigniewa Anusika Przyłuki zamiast Pryłuki? Nie do przyjęcia jest również propozycja nazwy Zadworze zamiast Zagorodzia pod Wiśniowcem. Nazwę tę wprawdzie zastosował w swoim atlasie Aleksander Jabłonowski, jednak nie występuje ona $\mathrm{w}$ żadnym znanym mi dokumencie do końca XVIII wieku. Z tego względu celowo i świadomie przyjęto zasadę podawania brzmienia nazw tak, jak zostały one zapisane w konkretnych dokumentach, tak również określano położenie miejscowości, bowiem granice województw czy powiatów także ulegały zmianom. Ponadto są też liczne miejscowości o identycznych nazwach, położone w różnych częściach kraju. Takie miejscowości spotykamy i wśród majątków Wiśniowieckich. Różne warianty nazw tych samych miejscowości zostały odnotowane $\mathrm{w}$ indeksie, co umożliwia czytelnikowi orientację. Jest też zupełnie oczywiste, że przy podziałach majętności wymieniane są zarówno klucze, jak i konkretne miejscowości, nie zawsze bowiem dzielono się wyłącznie kluczami. Oczywiste również, że niektóre majętności miały także i innych właścicieli, co nie wyklucza faktu posiadania części z nich również przez Wiśniowieckich. Było to zjawisko powszechne i negacja przez Zbigniewa Anusika posiadania niektórych majątków przez Wiśniowieckich $\mathrm{z}$ tego powodu, że posiadali je też inni właściciele, jest niezrozumiała.

To samo dotyczy nazwisk. Przejdźmy więc do konkretów. Na s. 155 Recenzent napisał co następuje: [...] zgodnie z tradycja rodowa Wiśniowieckich, małżonka kniazia Michała była nieznana z imienia kniaziówna Połubińska. Nazwisko tych kniaziów przybierało też niekiedy formę Połubieński. Herbarze nie notuja natomiast żadnych kniaziów Potubeńskich. Dziwić musi uznanie herbarzy za najwłaściwsze źródło do określenia formy nazwiska. Ale i tu mamy $\mathrm{w}$ istocie dużą różnorodność. Forma Połubiński występuje tylko u Niesieckiego i Okolskiego, u Paprockiego mamy formę Połubieński, a u Bonieckiego Połubeński. Pozwolę sobie przypomnieć, że pierwsze drukowane herbarze pojawiły się w Polsce w drugiej połowie wieku XVI, a te najbardziej znane pochodzą z końca XVIII i z XIX wieku, gdy obowiązywała już spolonizowana forma nazwiska. Tekst $w$ tym momencie dotyczy jednak wieku XV, w którym jedyną formą nazwiska kniaziów 
używaną w dokumentach była właśnie forma Połubeński ${ }^{6}$. Podobnie było zresztą jeszcze przez cały wiek XVI. Również wszelkie inne propozycje polonizacji nazwisk $\mathrm{w}$ czasach, kiedy ona jeszcze nie nastąpiła, uważam za bezzasadne. Tak więc, zgodnie z zapisem dokumentowym, pozostanę przy Skorutiance, Koptiu i innych.

Nadinterpretacją jest podane przez Recenzenta stwierdzenie (s. 156): Zupetnie bezzasadne jest jednak przypuszczenie, że Katarzyna ze Skorutów Wiśniowiecka, pochodzaca z rodziny posiadajacej dobra na Rusi Czerwonej oraz na Wołyniu, mogła odziedziczyć majętność Horki w powiecie mińskim. Twierdzenie to $\mathrm{w}$ istocie znacznie przerysowuje tekst, który $\mathrm{w}$ oryginale brzmiał (s. 36): W bliżej nieznanych okolicznościach, być może jako spadek, w jej posiadaniu znalazła się również majętność Horki także w powiecie mińskim. Nie ma tu żadnej wyraźnej sugestii, że był to spadek, a jedynie przypuszczenie wynikające $z$ braku informacji na temat okoliczności nabycia Horek. Ponadto spadek można otrzymać nie tylko po rodzicach, ale także po innych krewnych i fakt posiadania przez Skorutów majętności na Rusi Czerwonej bynajmniej nie przesądza o niemożliwości uzyskania przez Katarzynę spadku w okolicach Mińska. Niemniej, jak wspomniałam, nie twierdzę, że był to spadek.

Recenzent ma oczywiście prawo nie zgodzić się z moimi przypuszczeniami dotyczącymi dat urodzin Iwana Wiśniowieckiego i jego braci, twierdząc (s. 157): Za punkt wyjścia musimy wziać bowiem datę urodzin kniazia Michała. Skoro przyszedł on na świat około roku 1460 (raczej nie wcześniej, ze względu na daty życia jego ojca), to jego starszy syn - Aleksander mógł urodzić się właśnie około 1480 r. Skoro zaś Iwan był młodszy od tego ostatniego, to urodzit się zapewne najwcześniej w roku 1481, a być może nawet nieco później. Jeśli założymy, że młodszy brat Iwana - Fedor przyszedt na świat w roku 1483 lub nawet 1484, to i tak miał jeszcze dużo czasu, aby zastużyć się królowi Aleksandrowi Jagiellończykowi, który zmarł w Wilnie 19 sierpnia 1506 r. Próby szczegółowego ustalania dat narodzin w sytuacji, gdy poza informacją na temat starszeństwa i służby Fedora (starszego) u króla Aleksandra nie mamy żadnych danych, wydają się dość ryzykowne. Proponowane przez Zbigniewa Anusika daty narodzin synów Michała Wiśniowieckiego są oczywiście możliwe, a nawet bardzo prawdopodobne, ale też nie mamy żadnego konkretnego dowodu na ich poparcie.

${ }^{6}$ Tak np. w dokumentach Archiwum Ksiażąt Lubartowiczów Sanguszków w Stawucie, t. I, Lwów 1887, s. 178; t. VII, Lwów 1910, s. 312 i B. Gorczak, Katalog rękopisów Archiwum XX Sanguszków w Sławucie, w Sławucie 1902, s. 440. Zob. też m. in. J. Wolff, Kniaziowie litewsko-ruscy, Warszawa 1895, s. 368 i n. B. Paprocki używa formy Połubieński, B. Paprocki, Herby rycerstwa polskiego zebrane i wydane R[oku] P[ańskiego] 1584, wyd. K. J. Turowski, Kraków 1858, s. 856. 
Zarzucając autorce niedokładne wykorzystanie dokumentu popisu z roku 1528 i niewłaściwe ich zaszeregowanie majątkowe (s. 158-159) Recenzent $\mathrm{w}$ ogóle nie wziął pod uwagę, że istnieje kilka wariantów tego popisu, obejmujących różne części Wielkiego Księstwa Litewskiego. Dokument zacytowany przez Recenzenta nie został wykorzystany w książce i nie był podstawą klasyfikacji majątkowej rodziny, nie mógł więc być podstawą żadnych „bałamutnych" twierdzeń. Do porównania dochodów wykorzystano inny podobny dokument $\mathrm{z}$ tego samego roku, zawierający jednak nieco odmienne dane. W świetle tego dokumentu Wiśniowieccy znajdowali się na 10 pozycji, jak jednak zaznaczono wyraźnie, w istocie znajdowali się oni w dość licznej grupie możnowładców o porównywalnych, dość wysokich wprawdzie, lecz nie najwyższych dochodach. Pisząca te słowa nigdy nie ośmieliłaby się dokonywać dokładnej klasyfikacji majątkowej w odniesieniu do tej epoki, a zwłaszcza czynić to w oparciu o jeden dokument czy nawet kilka dokumentów podobnego rodzaju. Choćby ze względu na położenie na szlaku tatarskim liczba mieszkańców we włościach Wiśniowieckich musiała być niższa niż liczba mieszkańców w innych majątkach porównywalnych pod względem obszaru, lecz leżących w spokojniejszych okolicach. Z drugiej strony jednak dzięki położeniu majętności na głównych szlakach handlowych Wiśniowieccy czerpali znaczne zyski, np. z dróg. Zapewne nie wszystkie ich dochody były podstawą obliczania obciążeń wojskowych, już więc choćby tylko z tego względu należy zachować daleko idącą ostrożność przy tworzeniu gradacji. Dodać jeszcze należy, że autorka monografii o Wiśniowieckich zajmowała się dziejami jednej rodziny, nie prowadziła natomiast i nie zamierza prowadzić badań porównawczych dotyczących majętności możnowładztwa czy to polskiego, czy litewskiego, pozostawiając to pole Recenzentowi.

Nie są mi znane żadne materiały źródłowe na temat wniesienia do domu Wiśniowieckich przez Nastazję Olizarównę włości Kniehynin. Szanowny Recenzent, wyrażając przekonanie, że była to majętność pierwszej żony Iwana Wiśniowieckiego (s. 161), też nie powołał się na konkretne źródło, będę więc wdzięczna za jego wskazanie.

Szerzej wypada też ustosunkować się do stwierdzenia Recenzenta, które znalazło się na s. 163: W moim przekonaniu, sprawa ustalenia tego, kto był matka pozostałych (poza Katarzyna) dzieci Iwana Wiśniowieckiego, nie jest bynajmniej ani prosta, ani też przesądzona. Nie znamy bowiem ani daty śmierci Nastazji Olizarówny, ani daty ślubu Iwana z Magdalena Despotówną. Przyjęte przez Autorkę założenie, że Nastazja zmarła około 1533 r. okazało się zupełnie chybione. Jej śmierć mogła równie dobrze nastapić w drugiej połowie 1530, jak i na poczatku 1538 r. Wszystko zdaje sie jednak wskazywać na to, że zmarła ona 
raczej w końcu lat trzydziestych XVI stulecia. Z pewnościa można natomiast wysunać w tym miejscu inna jeszcze, zupetnie uprawniona hipotezę. Otóż wydaje się, że o ile Milica Despina i Helena (Jelena) Branković były rzeczywiście córkami despoty Jovana, to zarówno Magdalena Wiśniowiecka, jak i Hanna Sanguszkowa były córkami Heleny Jakšić z jej drugiego małżeństwa. Obie musiały bowiem przyjść na świat około 1510 r. (Magdalena raczej nieco później), przy czym starsza z sióstr Berisković była raczej Hanna, która wcześniej wyszła za maż i wcześniej zaczęła rodzić swoje dzieci.

Recenzent ma tu rację tylko w jednym wypadku. Rzeczywiście nie znamy daty śmierci Nastazji Olizarówny ani daty ślubu Iwana Wiśniowieckiego z despotówną Magdaleną. Przesłanki nie wskazują jednak, by mogło to nastąpić $\mathrm{w}$ końcu lat trzydziestych XVI wieku, albowiem niewątpliwie w roku 1538 urodził się drugi syn Iwana i Magdaleny - Andrzej. Zupełnie nieuprawnione jest postawienie przez Recenzenta drugiej hipotezy. Nie wiem, gdzie Recenzent znalazł rzekomo występujące w monografii nazwisko Berisković. Mimo intensywnych poszukiwań włącznie z użyciem przyrządów optycznych nie udało mi się znaleźć takiego jego zapisu ani w tekście książki, ani w indeksie. Nawet gdyby jednak jakiś chochlik drukarski się pojawił, Recenzent winien był sprawdzić, o kim mowa, a nie pisać o nieistniejącej rodzinie Beriskoviciów. Ivaniš Berislavić, bo taka forma nazwiska jest właściwa i tak została zapisana w monografii Wiśniowieckich, był mężem Heleny (Jeleny) Jakšić w latach 1504-1514. Otrzymał on również od króla węgierskiego tytuł despoty serbskiego po pierwszym mężu Heleny - Janie (Jovanie) Brankoviciu, zmarłym w 1502 r. Despotowina serbska jako odrębne państwo wprawdzie już wówczas nie istniała, jednak Brankovicie mieli na południu ówczesnych Węgier, głównie na terenie obecnej Wojwodiny, liczne prywatne posiadłości nadane im przez królów węgierskich ( $\mathrm{zw}$. Srem). Terytorium to do rozpadu Węgier i opanowania tych ziem przez Imperium Osmańskie było namiastką państwa serbskiego. Jako pierwszy tytuł despoty otrzymał od Macieja Korwina w roku 1471 Vuk Grgurević Branković, znany jako Ognisty Smok - Ognjeni Zmaj. Po bezpotomnej śmierci Vuka tytuł despoty otrzymał jego kuzyn Jerzy (Đorđe), a po wstąpieniu tegoż do klasztoru jego młodszy brat Jan7. Z Heleną Jakšić Jan Branković musiał ożenić się ok. roku 1490 i jak się powszechnie przyjmuje w literaturze, miał z nią pięć córek, wśród których figurują też Hanna i Maria Magdalena ${ }^{8}$. Nie ma żadnych materiałów źródłowych, które mogłyby wskazywać, że było inaczej. Jedynie z powodu późnych małżeństw i późnych ciąż Marii Magdaleny w przypi-

${ }^{7}$ Нова историја српског народа, уредник Д. Т. Батаковић, Београд 2000, s. 98.

${ }^{8}$ Родословне таблице и грбови српских династија и властеле, Београд 1991, s. 123 i 225 . 
sie 35 wyraziłam wątpliwość co do rzeczywistej możliwości jej pochodzenia z Brankoviciów, jednak nie ma żadnego dowodu źródłowego na to, że jej ojcem był Ivaniš Berislavić, przecież niektóre kobiety mogą rodzić dzieci również po czterdziestym roku życia. Wykorzystanie tej mojej wątpliwości do postawienia mi zarzutu i rozwijania w oparciu o nią dalszych hipotez (w dodatku bez znajomości podstawowych faktów dotyczących południowosłowiańskich dynastii - vide nazwisko Berisković) nie można traktować inaczej, jak nadużycie i czystą fantazję. Sprawę ustalenia ojcostwa Marii Magdaleny i Hanny utrudnia fakt, że we wszystkich, dość licznych zresztą dokumentach określane są one jedynie mianem „despotówien", a ten termin może się odnosić zarówno do ojcostwa Brankovicia, jak Berislavicia. Jaka była kolejność urodzin sióstr, nie wiemy, niewątpliwie najstarsza musiała być Milica, która najpóźniej w roku 1505 wyszła za mąż za Neagoe Basaraba, od roku 1512 hospodara wołoskiego. Kolejna była Maria, która ok. 1509 roku poślubiła chorwackiego wielmożę Ferdynanda Frangepana. Trzy kolejne siostry: Helena, Hanna i Magdalena były najprawdopodobniej w podobnym wieku, znacznie młodsze od Milicy oraz Marii i tylko tyle możemy powiedzieć na temat ich wieku. Możliwe, że wszystkie trzy młodsze despotówny wyszły za mąż późno ze względu na śmierć najbliższych członków rodziny i utratę rodowych posiadłości. Niewykluczone w końcu, że wydaniem ich za mąż zajęła się ciotka, siostra ich matki - Anna z Jakšiciów Glińska, babka Iwana IV Groźnego. Nota bene, to pokrewieństwo czyni jeszcze bardziej zrozumiałym okresowe przejście Dymitra Wiśniowieckiego na służbę moskiewską. Na temat Heleny wiemy, że wyszła za mąż za Piotra Rareşa w kwietniu 1530 r. Datę małżeństwa Hanny z Fedorem Sanguszką ustaliłam na przed rokiem 1535, co Recenzent mylnie interpretuje jako rok 1535, wykazując zupełnie słusznie małe prawdopodobieństwo tej daty (s. 164, p. 21).

Co do daty ślubu Marii Magdaleny z Iwanem Wiśniowieckim nie ma wprawdzie konkretnych informacji, ale są też pewne przesłanki nie tylko oparte o datę śmierci Nastazji Olizarówny. Recenzent ma wprawdzie rację, korygując datę śmierci Konstantego Ostrogskiego (pisząca te słowa przyjęła datę roczną 1533 zamieszczoną na nagrobku, istotnie przeczą jednak temu dokumenty wskazujące na jego śmierć już w roku 1530), co przesuwa możliwość śmierci Nastazji Olizarówny również na rok 1530, niemniej ważna jest tu również data śmierci brata Iwana Wiśniowieckiego - Fedora, który zmarł pomiędzy lutym a wrześniem 1533 r. Przez wiele lat toczył się spór między Fedorem a dworem mołdawskim o zwrot posagu zmarłej bezpotomnie jego pierwszej małżonki - hospodarówny mołdawskiej Marii. Zadziwiające jednak, że po śmierci Fedora sprawa natychmiast ucichła i hospodar mołdawski przestał domagać się czegokolwiek 
od jego spadkobierców, choć właśnie wówczas miał teoretycznie największe szanse odzyskania tego spadku. Wydaje się wielce prawdopodobne, że małżeństwo Iwana Wiśniowieckiego z siostrą hospodarowej mołdawskiej rozwiązało wieloletni spór. Nie ulega wątpliwości, że Magdalenę i jej najstarszego syna Dymitra (o dowodach na to, że był jej synem, jeszcze niżej) łączyły szczególnie bliskie związki z Heleną Rareş i jej dziećmi. Dlatego też uznałam za prawdopodobne przebywanie Magdaleny przed zamążpójściem na dworze mołdawskim jak też wydanie jej za mąż przez siostrę i szwagra.

Co do pozostałych dzieci Iwana Wiśniowieckiego to, wbrew sugestiom Zbigniewa Anusika, nie ma żadnych wątpliwości na temat tego, że ich matką była Brankoviciówna, źródła pozwalają bowiem na dość dokładne określenie ich wieku. Kolejny po Dymitrze syn, Andrzej, zmarł w listopadzie 1583 roku w wieku 45 lat, musiał więc urodzić się w roku 1538. Jego wiek $w$ chwili śmierci został zapisany na portrecie, nie jest to więc bynajmniej moje autorytarne stwierdzenie, jak twierdzi Recenzent. Michał (Zygmunt) i Konstanty byli młodsi od Andrzeja. Pierwszy z nich w chwili głośnego wypadku w Królewcu i śmierci w roku 1552 liczył lat 12, musiał więc urodzić się $\mathrm{w}$ roku 1540 . Konstanty był najmłodszy z rodzeństwa, niewątpliwie więc urodził się w roku 1541-1542. Nie mamy jedynie jasności co do daty urodzin Aleksandry, bez wątpienia jednak była ona córką Magdaleny, była przez nią wychowywana także po jej drugim zamążpójściu i została przez nią wyposażona.

Twierdzenie Recenzenta, że Dymitr Wiśniowiecki był pełnoletni w chwili śmierci Iwana Wiśniowieckiego (s. 165), mogłoby być uprawnione tylko wówczas, gdyby przyjąć, że był jego synem z pierwszego małżeństwa. Sprawa wieku Dymitra Wiśniowieckiego od kilku stuleci stwarzała problemy historykom i genealogom. Według niektórych miał on w chwili śmierci, a więc w roku 1563, liczyć nawet... 50 lat, a więc $\mathrm{w}$ takim wypadku musiałby urodzić się ok. roku 1513! Z tego względu figuruje on czasem w niektórych genealogiach nie jako syn Iwana, ale jako syn Michała Zbaraskiego-Wiśniowieckiego, co oczywiście wydaje się nie do przyjęcia jako sprzeczne z innymi źródłami. Możliwe jednak, że owe 50 lat wzięły się z błędnego odczytania 30 lat, co wskazuje na bardzo prawdopodobny rok urodzenia Dymitra - 1533. Logika nakazywała historykom tłumaczyć stosunkowo wczesną dorosłość Dymitra jego pochodzeniem od Nastazji Olizarówny. Logika nie może jednak zastępować materiału źródłowego, który niejednokrotnie okazuje się niezgodny z tym, czego moglibyśmy oczekiwać, kierując się wyłącznie logiką.

Dyskusji na temat pochodzenia Dymitra Wiśniowieckiego można się było spodziewać, dziwi jednak potraktowanie przez Recenzenta bardzo 
ostrożnie wysuniętej hipotezy, wskazującej jedynie na ewentualność pochodzenia księcia od kogoś z rodziny hospodarów mołdawskich, jako głównej tezy. Jak podkreśliłam $\mathrm{w}$ monografii i jeszcze raz podkreślam, jedynym pewnym ustaleniem w tej sprawie jest to, że Dymitr był synem despotówny Marii Magdaleny. Mamy na ten temat aż trzy jednoznaczne, niezależne od siebie i powstałe w różnym czasie przekazy źródłowe:

1. Przekaz doskonale poinformowanego Macieja Stryjkowskiego, korzystającego z mecenatu Hryhora Chodkiewicza, męża Katarzyny z Wiśniowieckich i przyrodniej siostry Dymitra: Kniaź Iwan Wiśniowiecki $z$ despotówny miat czterech synów: Dymitra, któregom w Turczech grób widziat, i Andrzeja, dzisiejszego wojewodę brasławskiego, Michała i Konstantyna9.

2. Przekaz Stanisława Bojanowskiego, który w liście do księcia Albrechta Hohenzollerna z dnia 28 maja 1549 r. pisał, że Dymitr i Eliasz Rareş są kuzynami ${ }^{10}$. Warto zaznaczyć, że w tym czasie wszyscy trzej synowie Piotra Rareşa znajdowali się w dobrym zdrowiu w Mołdawii i Dymitr Wiśniowiecki nie miał żadnego interesu $\mathrm{w}$ tym, aby uzurpować sobie związek rodzinny z mołdawską dynastią panującą.

3. Przekaz hospodara mołdawskiego Aleksandra Lăpuşneanu, który w instrukcji dla swego posła do Zygmunta Augusta z 29 lipca 1553 pisał o Dymitrze, że się zjednat z Mahmetem Iliaszem, bo sq obadwa od dwu sióstri1.

Do tego dodać należy jednoznaczny przekaz dokumentów spadkowych po Nastazji Olizarównie. Pogląd, że ta ostatnia była matką Dymitra, poza bardzo głębokim przekonaniem Zbigniewa Anusika, nie ma na swoje poparcie ani jednej informacji źródłowej.

Wiadomo też jednak, że Dymitr nie tylko jako jedyny z całej rodziny zgłaszał pretensje do tronu mołdawskiego, ale też owe pretensje zostały tam, przynajmniej przez niektóre kręgi, uznane. To dość dziwne przy założeniu, że nie był członkiem rodziny panującej. Nie twierdzę, że na pewno był synem Piotra Rareşa lub innego przedstawiciela mołdawskiej dynastii, lecz jedynie, że takiej ewentualności nie można wykluczyć. Wysuwane przez Recenzenta przypuszczenie, że miał on prawo do tronu mołdawskiego z powodu innych paranteli rodzinnych jest zupełnie bezzasadne, bo żadna ze wspomnianych przez niego rodzin (Olizarów,

${ }^{9}$ M. Stryjkowski, O początkach, wywodach, dzielnościach, sprawach rycerskich $i$ domowych stawnego narodu litewskiego, żmojdzkiego i ruskiego, przedtym nigdy od żadnego ani kuszone, ani opisane, z natchnienia Bożego, a uprzejmie pilnego doświadczenia, opr. J. Radziszewska, Warszawa 1978, s. 326.

${ }^{10} \mathrm{~N}$. Iorga, Nouveaux matériaux pour servir à l'histoire de Jacques Basilicos l'Heraclide dit Despote prince de Moldavie, Bucureşti 1900, s. 68-69.

${ }^{11}$ Archiwum Główne Akt Dawnych w Warszawie (AGAD), Libri Legationum, sygn. 14, k. 166v-169; I. Corfus, Documente privitoare la istoria României culese din arhivele polone. Secolul al XVI-lea, Bucureți 1979, s. 179. 
Ostrogskich, Bielskich i Holszańskich - s. 173) nie miała wśród swych przodków Muszatowiczów-Bogdanowiczów. Niektórzy, jak np. Holszańscy, wydawali wprawdzie za nich za mąż córki, nie żenili się jednak z hospodarównami. Nijak ma się również do tej kwestii podniesione przez Recenzenta porównanie kniazia Dymitra do Jakuba Heraklidesa czy Olbrachta Łaskiego. Pierwszy był cesarskim agentem, znakomicie przygotowanym do odegrania swej roli, zaopatrzonym $\mathrm{w}$ oryginalne dokumenty z kancelarii cesarza Karola V, poświadczające jego rzekome pochodzenie z rodu panującego na wyspach Samos, Paros i Naxos, a także rzekome pokrewieństwo z Brankoviciami ${ }^{12}$. Używając tu języka Recenzenta - mam nadzieję, że Recenzent zdaje sobie sprawę z tego, co znaczył wówczas dyplom cesarski! Także w Polsce, w czasach gdy Heraklides tu przebywał, nikt nie wątpił w jego pochodzenie, herb Bazylik, który nadał Cyprianowi z Sieradza przyjmując go do swego rodu, nigdy nie został zakwestionowany. Mimo to jednak Heraklides musiał zdobywać władzę siłą i przez znaczną część mołdawskich bojarów i społeczeństwa nigdy nie został uznany. Olbracht Łaski zaangażował w przedsięwzięcie Heraklidesa bardzo duże środki, za co ten oficjalnie uczynił go swym spadkobiercą ${ }^{13}$. Posiadanie tego dokumentu również nie zapewniło Łaskiemu uznania prawa do tronu, nie było to więc takie łatwe, jak próbuje sugerować Zbigniew Anusik. Oczywiście uzurpatorów było w Mołdawii mnóstwo, ale każdy z nich musiał przynajmniej udawać, że ma jakiś związek z dynastią. Oczywiście też zakładając, że despotówna Maria Magdalena przybyła na dwór Iwana Wiśniowieckiego niezupełnie sama, to przecież nie nastąpiło to za darmo, prawdopodobnie cała rodzina na tym zyskała (nie musiała zwracać posagu małżonki Fedora, a sama Maria Magdalena też wniosła sporo) i nie leżało w jej interesie nagłaśnianie tej sprawy, a do czasów plotkarskich salonów było jeszcze daleko.

Opisana przeze mnie działalność kniazia Dymitra Wiśniowieckiego także została mocno skrytykowana przez Zbigniewa Anusika, który napisał:

Nie wdając się już w szczegóty biografii kniazia Dymitra, poprzestańmy na wskazaniu jedynie kilku ewidentnych nieścisłości. Po pierwsze, nie przekonuje mnie twierdzenie Autorki ( $z$ powodów zasygnalizowanych powyżej), że sprawami mołdawskimi interesowat się Dymitr ze względu na interesy swojej bliskiej rodziny. Po drugie, zabrakło tu informacji, że w czasie walk o tron mołdawski w roku 1552 została zamordowana (uduszona) wdowa po Piotrze Rareşu - Helena (Jelena), siostra (zapewne przyrodnia) Magdaleny Wiśniowieckiej. Po trzecie, co ozna-

${ }^{12}$ Szerzej na ten temat I. Czamańska, Jakub Basilicos Heraklides - droga wyzwolenia Grecji??, „Balcanica Posnaniensia. Acta et studia” 1999, t. IX/X, s. 136.

${ }^{13}$ AGAD, Dokumenty Pergaminowe, sygn. 6904. 
cza sformułowanie, że latem 1553 r. Wiśniowiecki zdecydowat się na desperacki krok: wraz ze swym ludem wszedt w granice Turcji do sandżaku białogrodzkiego $z$ zamiarem połaczenia się z Mehmedem Eliaszem Rareşem, a być może w dalszej konsekwencji przejścia na służbę turecka (s. 72). Czy znaczy to, że Wiśniowiecki ruszył do Turcji na czele oddziału wojska, czy też wyprowadził ze swoich włości na Wołyniu poddanych, z którymi zamierzał przenieść się do państw suttana? Po czwarte, wydaje się watpliwe, aby Dymitr Wiśniowiecki otrzymat w 1554 r. od Zygmunta Augusta nadanie starostw czerkaskiego i kaniowskiego po Dymitrze Sanguszce (s. 73). Bardziej prawdopodobne jest, że oboma starostwami zarzadzali komisarze królewscy aż do chwili, gdy w 1559 r. nowym starosta zostat kuzyn Dymitra, kniaź Michał Wiśniowiecki (zm. 1584). Po piate, Dymitr Wiśniowiecki wznióst na wyspie Chortycy nie jakiś "zamek” (s. 73-74), ale umocniony obóz (najpewniej otoczony watami ziemnymi wzmocnionymi częstokołem), będacy pierwowzorem późniejszych siczy zaporoskich. Po szóste wreszcie, nie ma doprawdy żadnego powodu, aby przyjmować bałamutne stwierdzenia kronikarzy rumuńskich, iż Dymitr był żonaty z jakaś Piasecka czy Piaseczyńska i dostat się do niewoli wraz ze swoim szwagrem (s. 81-82). Wszystko wskazuje bowiem na to, że zmarł on bezżennie i bezpotomnie, a próby wywiedzenia od niego jakichś rodzin szlacheckich sa zwyktymi urojeniami.

W sprawie powiązań rodzinnych Dymitra powiedziano już wyżej dostatecznie dużo, w przypadku Rareşów są one niewątpliwe. O ile zrozumiałe są opory Recenzenta co do akceptacji tez nowych, może nieco dla niego szokujących, o tyle niezrozumiałe jest podważanie przez niego sprawy dobrze znanej i opisanej w literaturze, jaką była próba przejścia Dymitra na służbę turecką. Oczywiście nie mamy spisu członków drużyny kniazia, nie wiemy, jak była ona liczna i z kogo się rekrutowała, nie to jest zresztą istotne. Istotne jest, że nic innego jak sytuacja w Mołdawii i współpraca Dymitra z Mehmedem Eliaszem, mająca potwierdzenie źródłowe w korespondencji Aleksandra Lăpuşneanu, nie jest w stanie wytłumaczyć nagłej decyzji Dymitra przejścia na służbę turecka, a następnie równie nagłego jego wycofania się. Fakt, że aresztowanie Mehmeda Eliasza zbiegło się w czasie ze zmianą decyzji Wiśniowieckiego i jego powrotem do kraju, nie może być przypadkowy. O śmierci ciotki oczywiście można było wspomnieć, z tym że nie nastąpiła ona w roku 1552, jak sugeruje Recenzent, lecz dopiero jesienią roku 1553, prawdopodobnie z powodu wykrycia inspirowanej przez nią próby przewrotu ${ }^{14}$. W tym sensie jej śmierć mogła być rezultatem, między innymi, działań Dymitra, nie miała jednak już raczej wpływu na jego poczynania.

${ }^{14}$ C. Rezachevici, Cronologia domnilor din Ţara Românească şi Moldova, a. 1324-1881, vol. 1, Bucureşti 2001, s. 598. 
Zupełnie fałszywie przedstawiony został przez Recenzenta mój pogląd odnośnie do ewentualnych zabiegów Dymitra Wiśniowieckiego o rękę Halszki Ostrogskiej (s. 174). Pojawiające się w literaturze informacje, jakoby Dymitr Wiśniowiecki był jednym z konkurentów do ręki Halszki Ostrogskiej, zostały przeze mnie zanegowane, a nie potwierdzone, jak sugeruje to Zbigniew Anusik.

Podobnie rzecz się ma z kwestią rzekomego nadania Dymitrowi Wiśniowieckiemu starostw czerkaskiego i kaniowskiego. Określanie Dymitra jako starosty czerkaskiego i kaniowskiego jest powszechne w literaturze, należało się więc do tego ustosunkować. Jedyna możliwość nadania mu takiego starostwa istniała w roku 1554 po śmierci Dymitra Sanguszki, jednak, jak stwierdziłam, nie jest to pewne, nie znamy bowiem dokumentu, w którym Dymitr jednoznacznie nazwany byłby starosta czerkaskim i kaniowskim, a jedynie niektóre jego działania mogłyby na to wskazywać. Oczywiście zaakceptować można też wersję Zbigniewa Anusika, że starostwami tymi do roku 1559 zarządzali komisarze królewscy, pod warunkiem, że zostanie udokumentowana. Nie do przyjęcia jest natomiast ewidentne wypaczanie poglądów autorki recenzowanej książki.

Recenzent oczywiście ma prawo za częścią badaczy, a wbrew zdaniu piszącej te słowa, uznać, że Dymitr Wiśniowiecki był twórcą Siczy Zaporoskiej. Niemniej liczne nieścisłości zawiera jego stwierdzenie, że wznióst na wyspie Chortycy nie jakiś „zamek”, ale umocniony obóz (najpewniej otoczony wałami ziemnymi wzmocnionymi częstokołem), będacy pierwowzorem późniejszych siczy zaporoskich. W rzeczywistości pierwowzorem Siczy Zaporoskiej był kosz tatarski, a nie fortyfikacje Wiśniowieckiego. Na temat tego, co Dymitr Wiśniowiecki zbudował na Chortycy czy w okolicy tej wyspy, trwa od lat wielka dyskusja historyków i archeologów, która przytoczona została w monografii w bardzo obszernym przypisie 24 na s. 73 . Recenzent jest natomiast pewien, co tam było, całkowicie ignorując tę dyskusję i stawiając się w roli absolutnego eksperta. Opisane przez Zbigniewa Anusika umocnienia ziemne też zresztą wówczas określano mianem zamku. O zamku Chortycy pisał wyraźnie Bartosz Paprocki ${ }^{15}$. Rzecz w tym, że z powstaniem zamku wiązało się zobowiązanie miejscowych kozaków do

15 „Tam niedaleko jest zamek Chortycza, ktory był Wiśniowiecki postawił”, B. Paprocki, Herby rycerstwa polskiego , s. 157. Ponadto tenże Paprocki dając bardzo dokładny opis pobytu Samuela Zborowskiego na Niżu pisze o miejscu między porohami „kędy się kozacy chowają", które ewentualnie można by uznać za jakąś wczesną formę Siczy Zaporoskiej, nie było to jednak miejsce identyczne z zamkiem Wiśniowieckiego, do którego Zborowski się udawał i w którym zatrzymał się na nocleg. Nawiasem mówiąc w związku z tym nasuwa się pytanie, kiedy i przez kogo zamek ten został odbudowany, wiadomo bowiem, że Dymitr Wiśniowiecki budował go dwukrotnie i dwukrotnie został zniszczony przez Tatarów, niewątpliwie też był ruiną w czasie podróży Ericha Lassoty w roku 1594. 
służby zamkowej. Pierwszy zamek Wiśniowieckiego powstał na ziemiach wielkiego księcia, jednak bez jego zgody. Z czasem Zygmunt August zaakceptował fakt dokonany przez Wiśniowieckiego, miał on więc pełne prawo domagać się od miejscowych kozaków pełnienia służby. Krótko potem jednak zamek został zniszczony przez Tatarów, a sam Dymitr przeszedł na służbę moskiewską. Wykorzystywał w niej swoich dawnych kozackich podwładnych jako najemną siłę zbrojna, co jednak z Siczą nie miało niczego wspólnego. Osobiście jestem zdania, że oddolna organizacja kozaków, jaką była Sicz Zaporoska, była produktem ubocznym przemian, które nastąpiły po wcieleniu ziem ukraińskich do Korony i reformach ustrojowych po unii lubelskiej. Sytuacja społeczna, która przyczyniła się do powstania Siczy, nie istniała jeszcze w czasach Dymitra Wiśniowieckiego, jego działania miały charakter odgórny i nie można ich uznać za początek Siczy Zaporoskiej.

Poruszając sprawę rzekomego małżeństwa Dymitra Wiśniowieckiego, po raz kolejny, informację źródłową odnotowaną przeze mnie u kronikarza mołdawskiego Grigore Ureche próbuje Recenzent przedstawić jako mój pogląd na sprawę, "zapominając" o następnym zdaniu brzmiącym: Informacji tych nie można jednak zweryfikować za pomoca żadnego innego źródła. Również moje dalsze informacje na temat prób wywodzenia genealogii od Dymitra przez różne rody szlacheckie nie mają charakteru aprobującego i nie są moimi „urojeniami”, jak to sugeruje Recenzent.

A swoją drogą Grigore Ureche to bardzo solidny kronikarz; choć w tym wypadku wiadomość rzeczywiście jest wątpliwa, to zupełnie prawdopodobny jest jego opis wzięcia do niewoli i odesłania Dymitra do sułtana, a przede wszystkim przejęcia go przez orszak Aleksandra Lăpuşneanu i odesłania do Stambułu z odpowiednim listem. Przemilczając jednak te informacje, Zbigniew Anusik znów całkowicie wypacza myśl zawartą w tekście książki, pozwalając tu sobie zresztą na złośliwy komentarz: Okazuje się zatem, że w Stambule nic nie wiedziano o uzasadnionych jakoby pretensjach Dymitra Wiśniowieckiego do tronu hospodarskiego w Mołdawii i potraktowano go nie jak pretendenta, ale jak zwykłego najeźdźce szukajacego sławy i łupów na terenie kraju podlegającego władzy tureckiego sułtana. Pomijając fakt, że Wiśniowiecki o tron mołdawski dla siebie w Stambule się nie starał, wypada zaprotestować przeciw tego typu zabiegom Recenzenta, z rzetelną dyskusją naukową niemającym niczego wspólnego.

Z wyraźną niechęcią i powątpiewaniem odnosi się Recenzent do wszelkich informacji niewystępujących $\mathrm{w}$ dotychczasowej literaturze przedmiotu, nie starając się nawet skonfrontować ich z materiałem źródłowym zawartym w przypisach. A zatem na s. 167 pisze: Nie sa również bynajmniej pewne zamieszczone na kartach omawianej ksiażki informacje o jego 
pierwszych doświadczeniach militarnych. Ilona Czamańska twierdzi, że najpewniej w roku 1555 lub 1556 kniaź Michat wzią udział w bitwie z Turkami na polach białogrodzkich. "Co ciekawe, w starciu wzięło udział aż trzech kniaziów ze swymi nadwornymi pocztami: obok Michała Wiśniowieckiego także Roman Sanguszko oraz Ostafi Rużyński, którego wybrano na głównodowodzacego" (s. 53). Co jednak wydaje sie równie interesujace, o wydarzeniu tym nie wiedza nic autorzy biogramów obu wspomnianych tu kniaziów. Niestety, cytując moją wypowiedź Recenzent zupełnie pominął przypis, w którym podane zostało źródło informacji. Tym sposobem autorka monografii postawiona została na cenzurowanym za to, że autorzy biogramów Sanguszki i Rużyńskiego nie znali Epicedionu.

Z niewiadomego powodu Recenzent określenie „jedno z najbiedniejszych starostw" interpretuje jak "najbiedniejsze starostwo" (s.183), przytaczając oczywiście przykład starostwa żytomierskiego, biedniejszego od starostwa owruckiego, o którym była mowa.

Myli się Recenzent pisząc, że Michał Wiśniowiecki, ojciec Jeremiego, został otruty w grudniu 1615 roku (s. 184), z całą pewnością nastąpiło to bowiem w prawosławne, a nie katolickie święta Bożego Narodzenia, a więc 5 stycznia 1616 r. Dysponujemy źródłem dokładnie opisującym okoliczności jego śmierci i wiemy, że nastąpiła ona dwa dni po otruciu, a więc 7 stycznia ${ }^{16}$.

Nie do końca precyzyjne jest też wyjaśnienie na temat dziadków Rainy Wiśniowieckiej ze strony matki, skoro już Recenzent uznał za konieczne poruszanie tej sprawy, nienależącej bezpośrednio do tematu. 1. Kupiec grecki z Chocimia Jerzy Kattaratos ożenił się z Mołdawianką Krystyną z miejscowości Lozna/Lozani leżącej w okręgu Dorohoi w Mołdawii. Od nazwy tej miejscowości pisał się iz Lozan, de Lozna, Lozonschi, a po otrzymaniu w roku 1607 polskiego indygenatu - Łoziński. Tak więc żona Jeremiego Mohyły była Greczynką jedynie w połowie. Ciągle niewyjaśniona pozostaje jednak sprawa związku tej rodziny z węgierską, a właściwie seklerską rodziną Csomortány, o czym wspominają liczne polskie genealogie i co jest powodem kombinacji genealogicznych, niemających jednak żadnych konkretnych podstaw źródłowych. 2. Nieprawdą jest, że ojciec hospodarowej Elżbiety Mohyłowej na przełomie lat siedemdziesiątych i osiemdziesiątych XVI wieku przeniósł się na stałe do Rzeczypospolitej. Na terenie Rzeczypospolitej Jerzy Łoziński mieszkał

${ }^{16} \mathrm{Ch}$. de Ioppecourt, Histoire sommaire des choses plus memorables advenves aux derniers troubles de Moldavie ou sont descrites plusieurs batailles gaignees tant par les princes polonois, que par les Turcs et Tartares, Paris 1620 [wyd.] I. Barret; tu wyd. A. Papiu-Illarian, Tesauru de monumente istorice, t. II, Bucureşti 1863, s. 45. 
okresowo i to krótko. Większość życia spędził w Mołdawii, pełniąc w latach 1597-1610 z przerwami niezbyt wysoką funkcję pârcalaba (starosty) chocimskiego ${ }^{17}$.

Co do dóbr Uście, to sprawa była znacznie bardziej skomplikowana, niż sugeruje to Recenzent, popełniając w swej relacji liczne błędy. Majętność kupiona została w roku 1596 przez Jeremiego Mohyłę od Zofii Chodkiewiczowej z domu Mieleckiej $1^{\circ}$ voto Olelkowiczowej Słuckiej, jednak Mohyłowie już wcześniej pomieszkiwali bądź w tej, bądź w innej miejscowości Uście, leżącej blisko Śniatynia. Transakcję przeprowadzono formalnie na najstarszego syna Jeremiego Mohyły, Konstantego, ale jakieś części mieli tam również niektórzy bliscy Mohyłom bojarzy, np. Luca Stroici ${ }^{18}$. Ten ostatni też początkowo zarządzał majątkiem. Gdy Konstanty Mohyła został hospodarem, majętność musiała przejść na jego braci lub któregoś z braci. Majątkiem zarządzał wówczas brat hospodarowej Elżbiety, Wasyl Łoziński, który jednak zginął w roku 1613 w wyniku pojedynku z Janem Chańskim. W roku 1614 formalnym właścicielem Uścia został najmłodszy syn Jeremiego Mohyły - Bogdan. Ten w roku 1616 został wraz z matką i bratem wzięty do niewoli tureckiej, w której, zmuszony do przyjęcia islamu, zmarł wkrótce, podobno z powodu źle wykonanego zabiegu obrzezania. Po jego śmierci majętność dziedziczyły mieszkające w Polsce cztery siostry, faktycznie jednak znajdowała się ona w posiadaniu Koreckich jako zastaw za pożyczkę 80000 złotych, udzieloną Elżbiecie Mohyłowej przez jej zięcia Samuela Koreckiego ${ }^{19}$. Spowodowało to wieloletni spór sądowy między siostrami i ich mężami. Cała sprawa wymaga jednak jeszcze szczegółowych badań Akt Grodzkich i Ziemskich w Centralnym Państwowym Archiwum Historycznym we Lwowie. To ogromny materiał, jak się zdaje, przez nikogo w całości nieprzeczytany. Władysława Łozińskiego, który jako pierwszy opisał walki o Uście, interesowały raczej kwestie sposobu dochodzenia prawa, a nie rzeczywista sytuacja prawna majętności. Nie wiadomo też, czy czytał on dokładnie wszystkie dokumenty, czy może tylko ich regesty, bowiem bardzo liczne błędy i uproszczenia mogłyby wskazywać na to ostatnie. Walki o Uście, wbrew twierdzeniu Zbigniewa Anusika, nie mogły być w roku 1623 toczone przez Samuela Koreckiego z Maksymilianem Przerembskim ani tym bardziej osoby te nie mogły za-

${ }^{17}$ Zob. m. in. N. Stoicescu, Dicționar al marilor dregători din Ţara Românească şi Moldova. Sec. XIV-XVII, Bucureşti 1971, s. 307.

${ }^{18}$ AGAD, Archiwum Zamoyskich, sygn. 697, p. 65-66, Luca Stroici do Jana Zamoyskiego, Uście, 11 X 1598 r.

19 Series documentorum domui Mohylovianae servientium ex Acta Haliciensibus et Trębovliensibus authentice depromptorum. Archiwum Narodowe w Krakowie (ANK), Archiwum Sanguszków, Teka 446/16 knlb. 
wierać wówczas ze sobą jakiejkolwiek umowy! Jak bowiem powszechnie wiadomo, Samuel Korecki znajdował się od roku 1620 w niewoli tureckiej, w której zginął zamordowany w roku 1622 . Z podobnego powodu nie mogła też uczestniczyć w sporach o Uście w latach dwudziestych XVII wieku zmarła w roku 1619 Raina Wiśniowiecka.

Niewątpliwie w roku 1629 części Uścia należące do Anny Przerembskiej (wraz z wcześniej przez nią zakupioną częścią Wiśniowieckich) zostały sprzedane Mironowi Barnowskiemu. Po jego bezpotomnej śmierci istotnie, jako kaduk, zostały nadane hetmanowi Koniecpolskiemu. Gdyby jednak Szanowny Recenzent doczytał choćby książkę Władysława Łozińskiego Prawem i lewem, na którą się powołuje, jeszcze dwie strony dalej, znalazłby tam informację, że Przerembscy odwołali się od tej decyzji, udowadniając, że Barnowski (rum. Barnovschi) nie zapłacił im całej sumy. O tym, że było to prawda, świadczy testament Mirona Barnowskiego i jego prawdopodobne zatajenie. W testamencie Barnowski odsuwał wszystkich swoich krewnych od spadku dóbr posiadanych w Polsce, które miały wrócić do Przerembskich po zwrocie przez nich wpłaconych przez niego $120000 \mathrm{zł}^{20}$, czyli 3/4 całej sumy sprzedażnej wynoszącej $160000 \mathrm{zł}$ (a nie jak u Łozińskiego 360000 - sprawdziłam w oryginale ${ }^{21}$ ). Prawdopodobnie Przerembscy nie otrzymali jednak testamentu Mirona Barnowskiego i nie mieli dostatecznie mocnego dowodu na to, że suma nie została zapłacona, wobec tego wszystkie cztery córki Jeremiego Mohyły lub ich dzieci wystąpiły z pretensjami do spadku po Barnowskim jako jego najbliżsi krewni mieszkający w Polsce ${ }^{22}$. Z materiałów zachowanych w Archiwum Sanguszków wiadomo, że sprawa ciągnęła się wiele lat i dopiero w roku 1664 Anna Mohylanka, wówczas już małżonka hetmana Stanisława „Revery" Potockiego, dobiła swego. Transakcja sprzedaży Uścia Barnowskiemu została anulowana i nastąpiła faktyczna intromisja ciotecznej babki Michała Korybuta Wiśniowieckiego do tej majętności. W styczniu 1669 roku przyszły król bez wątpienia odziedziczył część Uścia po zmarłym bez-

${ }^{20}$ Testament był publikowany kilkakrotnie, m.in.: B. Petriceicu Hașdeu, „Arhiva Istorică a României", vol. 1/2, s. 187-190; Documente Romaniae Historica, A, t. 21, București 1971, s. 424-427; A. H. Golimaș, Un domnitor. O epocă. Vremea lui Miron Barnovschi Moghilă, voievod al Moldovei, București 1980, s. 207-211.

${ }^{21}$ Umowa sprzedaży Uścia między Mironem Barnovschim a Anną i Maksymilianem Przerembskimi z r. 1629, obl. 1639 - Centralnyj Deržavnyj Istoričeskij Arhiv, Lviv (CDIA Lviv), f. 17, Akta Grodzkie, Trembowla 122, s. 893-896. Tekst brzmi dosłownie: „o groszy trzydziestu sto sześćdziesiąt tysięcy" (s. 894).

${ }^{22}$ Szerzej na ten temat: I. Czamańska, Miron Barnovschi i jego rodzina w relacjach $z$ Polakami, [w:] Wielowiekowe bogactwo polsko-rumuńskich zwiazków historycznych i kulturowych, Suceava 2014, s. 79-89. 
potomnie kuzynie swego ojca - Zygmuncie Przerembskim ${ }^{23}$. W żadnym wypadku więc nie otrzymał tej majętności od Koniecpolskich, jak to sugeruje Recenzent!

Nie wiadomo, na jakiej podstawie Zbigniew Anusik podaje w wątpliwość, że córka Michała Wiśniowieckiego i siostra Jeremiego miała na imię Anna Konstancja. Księżniczka podpisywała się zawsze dwojgiem imion, co łatwo sprawdzić, zachowało się bowiem kilka jej listów w polskich zbiorach. Jej rzekomo bajeczny posag, o którym pisze Recenzent na podstawie starszej literatury, był zupełną fikcją. Zachowały się oryginalne materiały zawierające dokładne rozliczenia $\mathrm{z}$ wypłaty jej posagu. W rzeczywistości otrzymała wszystkiego 200000 zł, jak na księżniczkę Wiśniowiecką - standard ${ }^{24}$. Nic też nie wskazuje na to, by miała mieć ze Zbigniewem Firlejem dwóch synów. Ze źródeł znamy tylko jednego syna - Mikołaja. Błąd Niesieckiego w tej sprawie został już dawno skorygowany przez Władysława Czaplińskiego w biogramie Zbigniewa Firleja w PSB ${ }^{25}$. Ponadto nie mamy żadnych śladów życia Anny już po roku 1641, niewykluczone więc, że zmarła znacznie wcześniej niż w roku 1647, proponowanym przez Z. Anusika.

Zupełnym nadużyciem jest tekst Recenzenta (s. 186): $W$ roku następnym Zbigniew Firlej poślubił bowiem Katarzynę, córkę marszałka wielkiego koronnego Łukasza Opalińskiego i jego drugiej żony - Zofii Daniłowiczówny. Jeśli wierzyć temu, że ślub jej rodziców odbyt się w 1636 r., to w chwili swego zamażpójścia druga żona starosty lubelskiego miała zaledwie 11 lat. Sugeruje on, że są to informacje pochodzące z mojej książki, a to już zupełna manipulacja. Poza powszechnie przyjętą w literaturze przedmiotu informacją o poślubieniu przez Firleja Katarzyny Opalińskiej nie podałam żadnych bliższych danych, kim byli jej rodzice, tym bardziej więc nie ożeniłam Firleja z 11-letnią dziewczynką.

Za kolejną manipulację uznać też trzeba przedstawienie moich wątpliwości co do rozbieżności w tekście i tablicach genealogicznych, występujących w literaturze przedmiotu jako mojego błędu! (s. 187) Nie wymyśliłam Macieja Zbaraskiego, postać taka znalazła się w genealogii, do której ustosunkowałam się krytycznie!

${ }^{23}$ Series documentorum domui Mohylovianae servientium ex Acta Haliciensibus et Trębovliensibus authentice depromptorum. ANK, Archiwum Sanguszków, Teka 446/16.

${ }^{24}$ Narodnyj Istoričeskij Archiv Belorusi, Mińsk, f. 694. op. 1, d. 9, p. 55, Zapis wieczystej darowizny Rohmanowa, Krzemieniec, 24 X 1640; Biblioteki Kórnicka, Rękopisy, sygn. 1946, k. 67-69, Rachunki z wypłaty 1/3 sumy posagu 66666 zł oraz ubezpieczenie na taką sumę.

${ }^{25}$ W. Czapliński, Firlej Zbigniew, Polski Słownik Biograficzny , t. VII, Kraków 19381948, s. 17. 
Niewłaściwa jest też interpretacja mojego tekstu, zaprezentowana na s. 188:

Kiedy zaś po śmierci siostry Ewy, wdowy po Piotrze ks. Zbaraskim, kniaź Adam przeją jej majątki, to były wśród nich także dobra Horłowicze vel Aleksandrowo, a nie jakieś Horłowskie i Aleksandrowo (Autorka konsekwentnie rozdziela jedna miejscowość mająca dwie różne nazwy na dwie odrębne miejscowości).

Aleksandrowo było wówczas głównym miastem klucza, natomiast cała włość nazywała się Horłowską lub Horłowskim. Z nazwą Horłowicze nie spotkałam się w dokumentach pochodzących z czasów, gdy gospodarowali tam Wiśniowieccy. Co wchodziło w skład włości, podano dokładnie w przypisie 11 na s. 135 i figuruje tam również Aleksandrowo jako główny ośrodek tej majętności, a nie jako odrębna majętność. Inna rzecz, że w dokumentach często zapisywano „Horłowskie z Aleksandrowem”.

Poniżej na tej samej stronie po raz kolejny przypisano mi pogląd dokładnie odwrotny do tego, który został przeze mnie wyrażony w rzeczywistości:

Autorka bez wahania przyjmuje wersje rozpowszechniana współcześnie przez dwór moskiewski, że Samozwaniec naprawde nazywał się Jurij Otriepiew i był mnichem, który z niskich pobudek sprzeniewierzył się swojemu powołaniu i porzucit habit.

Tymczasem na s. 136 napisałam wyraźnie:

Sprawa Dymitra Samozwańca, mimo że interesowata tak wielu badaczy, nie została definitywnie wyjaśniona. Możliwości uratowania carewicza, niezależnie od watpliwości, ciagle nie można wykluczyć. Definitywna odpowiedź mogłyby dać badania DNA pozostałości Iwana IV i dziecka pochowanego jako Dymitr, o takich jednak, jak dotad, nie wiadomo. Wiele wskazywało na to, że młody człowiek mógł być uratowanym carewiczem: 1) pochodzit z Uglicza, 2) byt w tym samym wieku co Dymitr, 3) posiadat pewne fizyczne cechy podobieństwa do Iwana IV. To oczywiste, że mieszkajac w Rosji i chcąc przeżyć za rządów Borysa Godunowa, nie mógt nazywać się Dymitrem Iwanowiczem. W istocie sprawa autentyczności pierwszego Samozwańca wydaje się tu drugorzędna. Czy byt, czy też nie byt carewiczem, byt idealnym kandydatem, by taka rolę odegrać, zwłaszcza na fali ogromnego niezadowolenia w Rosji z rządów Godunowa.

Wbrew twierdzeniu Recenzenta, że Śniatyń i Pryłuki (tylko takiej nazwy można używać w odniesieniu do miasta na Zadnieprzu) z pewnościa 
nie były sporne z Moskwa, gdyż oba leżały w odległości kilkudziesięciu kilometrów od granicy, mamy liczne przekazy źródłowe świadczące o pretensjach moskiewskich do Zadnieprza, a także konkretnie do tych miasteczek ${ }^{26}$. Jeśli Zbigniew Anusik twierdzi, że było inaczej, to oczekiwać należy dowodu, że źródła te są niewiarygodne lub zostały niewłaściwie zinterpretowane.

Niesłusznie neguje też Recenzent posiadanie przez Wiśniowieckich Myszy i wniesienia jej do rodziny przez Katarzynę Korniaktównę (s. 191). Posiadanie przez Wiśniowieckich Myszy i realne ich w niej gospodarowanie jest faktem niewątpliwym, wyjątkowo dobrze oświetlonym źródłami ${ }^{27}$. Wprawdzie w drugiej wersji recenzji, opublikowanej w Studiach $i$ szkicach staropolskich, Zbigniew Anusik wycofał się z całkowitej negacji tego faktu wyrażonej $\mathrm{w}$ pierwszej wersji, jednak i w tym wypadku zaproponował wyjaśnienie, z którym trudno się zgodzić. Stwierdził bowiem, zupełnie nie wiadomo na jakiej podstawie, że majętności te odziedziczyli Wiśniowieccy po Januszu Skuminie Tyszkiewiczu. Po pierwsze, nie wiadomo o tym, by Tyszkiewicz miał jakieś udziały w Myszy, po drugie, gdyby tak było, to jakim prawem współwłaścicielką Myszy byłaby również Konstancja Wiśniowiecka, córka Jerzego? Wiadomo, że Mysz znajdowała się w rękach Wiśniowieckich co najmniej od połowy XVII wieku, jednak jakim sposobem trafiła do tej rodziny, nie wiadomo, osoba Katarzyny Korniaktówny wydaje się tu jedynym możliwym ogniwem powiązań rodzinnych, w wyniku których Mysz mogłaby przejść od Chodkiewiczów do Wiśniowieckich. Oczywiście i w tym wypadku jest to przypuszczenie - nic więcej. Nie oznacza to, że Wiśniowieccy posiadali całą Mysz, prawdopodobnie była to niewielka część majątku z folwarkiem, jednak fakt posiadania przez nich dóbr w Myszy nie ulega żadnej wątpliwości.

Neguje też Recenzent pokrewieństwo Stanisława Warszyckiego z Łubieńskimi (s. 195). Tymczasem Stanisław Łubieński niemal w każdym liście do Konstantego i Janusza Wiśniowieckich wspomina o swoim pokrewieństwie z Warszyckim, musiało więc ono być faktem, choć nie wiadomo, jakiego rodzaju było to pokrewieństwo. Uściślenia i korekty Recenzenta na temat samego Warszyckiego są w większości słuszne, jednak jeśli autorka o czymś nie pisze, to nie musi znaczyć, że tego nie wie

\footnotetext{
${ }^{26} \mathrm{~Np}$. poselstwo Grigorija Ogariewa - Сборник Императорского Российского Исторического Общества, t. 137, Moskwa 1912, s. 176.

${ }^{27}$ Biblioteka Czartpryskich, Rękopisy, sygn. 4509, Inwentarz myski z roku 1650; Biblioteka Uniwersytetu Warszawskiego, Zbiór rękopisów, sygn. 317, p. 82-83, Pozew Trojana Wołłowicza przeciw ks. Wiśniowieckim o chłopów zbiegłych do ich majętności Myszy, 15 I 1655 r.; p. 85, Oświadczenie Samuela Zwiartowskiego w sprawie próby odebrania zbiegłych chłopów; p. 84, Oświadczenie w sprawie złożenia pozwu; p. 87, Sprawa Trojana Wołłowicza z ks. Wiśniowieckimi na rokach nowogrodzkich, 04 VI 1655 r.; zob. też Biblioteka Czartoryskich, Rękopisy, sygn. 4511, 4515, 4519.
} 
(choć oczywiście nie jest wszechwiedząca). Wypada uściślić, że Domicella Wierzbowska była druga, a nie pierwszą małżonką Jana Kazimierza Warszyckiego, szczęściem Recenzent poprawił ten błąd w drugiej wersji. Sugestia, jakoby napisano, że Andrzej Trzebicki był arcybiskupem gnieźnieńskim, to jednak kolejna manipulacja.

W pewnym sensie za manipulację uznać też należy „obciążenie” autorki za wszelkie niezgodne z poglądami Recenzenta informacje zaczerpnięte $\mathrm{z}$ literatury, w tym $\mathrm{np}$. informacje dotyczące dwóch żon Konstantego Wiśniowieckiego: Katarzyny Korniaktówny i Krystyny Strusiówny. Wbrew insynuacjom $Z$. Anusika nie ma też $\mathrm{w}$ napisanym przeze mnie biogramie Krystyny Strusiówny mowy o wniesieniu przez nią dóbr do domu Wiśniowieckich, mowa jest o ich prawdopodobnym posiadaniu i wydzierżawieniu, o czym świadczy zaprezentowany materiał źródłowy.

Zarzucając autorce zbyt małe zainteresowanie sprawami majątkowymi Jeremiego [s. 199], Recenzent niewiele wnosi, zwracając jedynie uwagę na podawaną $\mathrm{w}$ literaturze liczbę 38 tys. gospodarstw chłopskich na Zadnieprzu. Należy jednak podchodzić ostrożnie do tych danych. Trzeba zwrócić uwagę, że liczba gospodarstw na tym terenie ulegała znacznym wahaniom, a okresy dobrej koniunktury przeplatały się z okresami wyludnienia. Najazdy tatarskie czy powstania kozackie gwałtownie zmieniały statystyki. Do tego dodać należy coraz częstsze ucieczki chłopów na Zaporoże. Niewątpliwie była to jedna $z$ istotnych przyczyn dążenia Jeremiego do przejęcia pod kontrolę terytorium za porohami Dniepru i likwidacji Siczy Zaporoskiej. Tradycyjnie jednak mój pogląd, związany z nadaniem Jeremiemu Chortycy i innych ziem za porohami Dniepru, został zinterpretowany w sposób daleki od rzeczywistych intencji wyrażonych w monografii. Na s. 200 Recenzent napisał: $W$ tym miejscu wypada zadać tylko jedno, ale za to absolutnie kluczowe pytanie. Skoro Jeremi Wiśniowiecki nic nie wiedziat o tym nadaniu, to skad wiedzieli o nim Chmielnicki i Kozacy? Nie wydaje się również prawdopodobne, aby Władystaw IV, próbujący wykorzystać Kozaków do sprowokowania wojny z Turcja, prowadzit z nimi jednocześnie makiaweliczna gre zmierzająca do całkowitej likwidacji Kozaczyzny Zaporoskiej. Niewątpliwie Jeremi nigdy nie otrzymał dokumentu, ale przecież, jak napisałam, niemożliwe, by o nim nie wiedział. Musiał dostać już znacznie wcześniej przyrzeczenie tego nadania. Prawdopodobnie była to cena za jego ostateczne poparcie planów wojny tureckiej. Rezultatem tego była jego wyprawa za porohy w roku 1647 i usypanie tam kopców granicznych, bo tak niewątpliwie należy interpretować informację Bogusława Maskiewicza o pozostawieniu kopca z herbem Wiśniowieckiego na Zaporożu! Kozacy o dokumencie pewnie nie wiedzieli, ale kopce musieli widzieć i z pewnością musieli dostrzec wynikające z tego niebezpieczeń- 
stwo dla siebie. „Makiaweliczna gra” króla była faktem, bowiem faktem bezspornym i namacalnym jest istnienie oryginalnego podpisanego przez niego dokumentu - nadania dla Jeremiego ${ }^{28}$. Zapewne też zresztą ani król, ani początkowo Wiśniowiecki nie myśleli o likwidacji Siczy, lecz o jej pełnym podporządkowaniu. Jednym $z$ ważnych zobowiązań, związanych z powyższym nadaniem, było zadanie zorganizowania na tym terytorium obrony. Nie twierdziłam i nie twierdzę, że dążenie Wiśniowieckiego do opanowania Zaporoża było główną przyczyną wybuchu powstania kozackiego, niemniej musiało to wpłynąć niekorzystnie na nastroje nie tylko Kozaków, ale i ludności ziem ukraińskich wobec Jeremiego Wiśniowieckiego.

Trudno też w pełni zgodzić się ze stwierdzeniem Recenzenta, że $w 1648$ r. Bohdanowi Chmielnickiemu z pewnościa nawet sie jeszcze nie śniło, że stanie on w przyszłości przed realna szansa utworzenia niezależnego państwa kozackiego (s. 201). Sojusz z Tatarami i próba poddania się Turcji, podjęta już latem 1648 roku, wyraźnie świadczą o tym, że brał to pod uwagę. Wyrażał też taki zamiar w czasie negocjacji z Adamem Kisielem. Oczywiście w tym czasie pewnie i dla samego Chmielnickiego brzmiało to jeszcze jak mało realna pogróżka, jednak już zostało sformułowane.

Niezrozumiałe i wyrwane z kontekstu są wątpliwości związane z powierzeniem Jeremiemu Wiśniowieckiemu naczelnego dowództwa nad wojskiem (s. 201) i określaniem go mianem „hetmana”. Jest sprawą zupełnie oczywista, że nie chodziło tu o pozbawienie władzy znajdujących się w niewoli hetmanów, ale o tymczasowe naczelne dowództwo, co wynika z całego kontekstu. On sam zresztą podpisywał wówczas dokumenty określając się jako „hetman na ten czas”.

Za niewłaściwe uznać należy podważanie wiarygodności ustaleń poprzez przemilczanie informacji przytaczanych przeze mnie źródeł i zastępowanie ich innymi, niewiążącymi się bezpośrednio $\mathrm{z}$ omawianą sprawą. Na przykład Recenzent całkowicie zignorował dokument podziału majątku między dzieci Katarzyny z Ostrogskich Zamoyskiej, zastępując go informacjami $\mathrm{z}$ innego dokumentu, dotyczącego podziału majętności między siostrami Ostrogskimi. Ani Ostrogscy, ani Zamoyscy nie byli przedmiotem moich badań, interesowała mnie tylko Gryzelda z Zamoyskich Wiśniowiecka i jej dokumenty. Z drugiej strony tego spadku po matce fizycznie nigdy nie objęła, zadowalając się spłatą w gotówce, dlatego też nie było sensu przytaczać wielostronicowego spisu wszystkich miejscowości, które na nią przypadały, a które natychmiast odsprzedała bratu.

\footnotetext{
${ }^{28}$ AGAD, Dokumenty Pergaminowe, sygn. 8916.
} 
Podważa też Recenzent podane przeze mnie informacje na temat okoliczności rozwodu Katarzyny Eugenii Tyszkiewiczówny z ostatnim mężem Aleksandrem Radziwiłłem, choć tym razem to nic nowego, lecz informacje od dawna obecne w literaturze i dobrze oświetlone źródłami (s. 211). Do kogo miałaby udawać się Katarzyna Tyszkiewiczówna, uciekając od ostatniego męża - Aleksandra Radziwiłła? Według niewątpliwie dobrze zorientowanego $\mathrm{w}$ tej sprawie Albrychta Stanisława Radziwiłła była to kobieta, którą dotychczasowa literatura identyfikowała z Anną Zbaraską. Zupełnie chybione jest twierdzenie Recenzenta, że Katarzyna Eugenia wyjechała od męża z powodu śmierci ojca, gdyż Janusz Tyszkiewicz zmarł dopiero 27 maja 1642 roku, gdy sprawa rozwodowa jego córki była w toku.

Nadużyciem wydaje się też stałe zresztą przytaczanie używanych powszechnie określeń dotyczących instytucji sądowych różnych instancji jako błędnych czy rzekomo nieistniejących. W epoce staropolskiej ogólnie używano nazwy Trybunał Lubelski na określenie sądu Trybunału Głównego Królestwa Polskiego w Lublinie, niewątpliwie też roki sądowe dla szlachty odbywały się np. w Krzemieńcu czy Bracławiu i określano je, także w oficjalnych dokumentach, mianem sądów ziemskich czy trybunałów.

Wbrew twierdzeniu Zbigniewa Anusika (s. 214) Michał Tomasz, król Polski, nie urodził się 1 czerwca, lecz według świadectwa samej jego matki 31 maja $1640 \mathrm{r}^{29}$, ze względu jednak na to, że również 31 maja urodziła się jego małżonka, przesunął obchody swoich urodzin na 1 czerwca.

Niewątpliwie król Michał, podobnie jak jego ojciec, był przynajmniej formalnie właścicielem Taraża. Włość ta była rzeczywiście własnością Aleksandry z Wiśniowieckich 1 voto Czartoryskiej 2 voto Łahodowskiej, która zachowała ją do swej śmierci, później jednak znajdowała się we wszystkich spisach majętności Jeremiego Wiśniowieckiego i jego syna. Skoro Recenzent znajduje tę majętność również u Czartoryskich, to możliwe, że każda z rodzin miała tam swoją część.

$\mathrm{Na}$ temat kwestionowanego przez Recenzenta „rodzinnego" porozumienia w sprawie elekcji Michała Wiśniowieckiego na tron polski pisała szeroko Mieczysława Chmielewska ${ }^{30}$. Dotyczyło ono Pawła i Jana Potockich, kuzynów ojca Michała, oraz żonatego z ich siostrzenicą Bogusława Radziwiłła, starającego się zresztą zapewnić odpowiednie profity dla swoich dalszych krewnych. Porozumienie miało charakter tajny i jego uczestnicy oficjalnie popierali innych kandydatów.

${ }^{29}$ B. Rudomicz, Efemeros czyli diariusz prywatny pisany w Zamościu w latach 1656-1672, przekł. W. Froch, cz. 2, Lublin 2002, s. 334.

${ }^{30}$ M. Chmielewska, Sejm elekcyjny Michała Korybuta Wiśniowieckiego 1669 roku, Warszawa 2006. 
Recenzent zdecydowanie przesadził, twierdząc, że nadanie królowi Michałowi przez 8-letniego króla Hiszpanii Orderu Złotego Runa to działanie cesarskiej dyplomacji. Nie ma na to żadnego dowodu źródłowego, a nadawanie tego orderu królom polskim było na dworze hiszpańskim tradycją. W Hiszpanii, jak w każdym kraju, niezależnie od wieku i predyspozycji umysłowych króla, byli urzędnicy, którzy podejmowali decyzję w jego imieniu.

To, co pisze Szanowny Recenzent na temat romansu Dymitra Wiśniowieckiego i Katarzyny Sobieskiej, zakrawa na "komedyję z Plauta”, jakby powiedział Jan Zamoyski. Wyśmiewając wręcz wcześniej możliwość adopcji Dymitra Wiśniowieckiego przez Iwana Wiśniowieckiego, Zbigniew Anusik przyjmuje za prawdę rzecz zupełnie nieprawdopodobną. Według Recenzenta Katarzyna Sobieska, będąc w ciąży z Dymitrem Wiśniowieckim, którego z wzajemnością darzyła uczuciem, została przez matkę zmuszona do poślubienia kogoś innego niż ojciec jej dziecka. Książę Władysław Dominik Zasławski-Ostrogski, uchodzący za najbogatszego magnata w Rzeczypospolitej, mógł być ewentualnie uznany przez matkę Katarzyny za lepszą partię dla córki od młodego Dymitra, ale jakiż on miałby interes $\mathrm{w}$ tym, aby żenić się z kobietą $\mathrm{w}$ zaawansowanej ciąży z kimś innym, ani najpiękniejsza, ani najbogatsza, i uznawać jej dziecko za własne? Co więcej, o ojcostwie Dymitra (o którym musiałoby być głośno w Rzeczypospolitej) nigdy się nie dowiedziała wychowująca go ks. Gryzelda, która później zamierzała wydać za mąż tegoż córkę za jego rzekomego naturalnego syna, a rzecz to pewna, bo zapisana w jej własnym testamencie. Warto też przyjrzeć się portretom. Młody Ostrogski nie wykazuje żadnych cech podobieństwa do ks. Dymitra, a do Zasławskiego i owszem. Wreszcie w czerwcu 1649 roku, kiedy ewentualnie musiałoby dojść do zbliżenia, Dymitr Wiśniowiecki znajdował się w Zbarażu, w miejscu odległym od Oleska Sobieskich o $87 \mathrm{~km}$. Wiemy bowiem z opisu Jana Białobockiego, że Jeremi Wiśniowiecki w połowie tego miesiąca, na wieść o marszu wojsk kozacko-tatarskich na Zbaraż, wyruszył natychmiast do znajdujących się w Zbarażu młodych książąt Wiśniowieckich - Dymitra i Konstantego.

Zarzucając mi niewłaściwe policzenie majętności Dymitra Wiśniowieckiego i rzekome nieprzestudiowanie dokumentów, Recenzent nie dostrzegł, że rzekomo niezgodna z rzeczywistością liczba miejscowości jest częścią cytowanego dokumentu ${ }^{31}$. Jako znawca przedmiotu Recenzent powinien wiedzieć, że $\mathrm{w}$ tego typu dokumentach zapisywano nie tylko miejsca zamieszkane, ale także uroczyska i ogólnie miejsca posiadające

${ }^{31}$ Dotyczy to dokumentu podziału majętności ukraińskich. CDIA Lviv, f. 181, op. 1, spr. 4172 , p. 2. 
nazwę, które nadawały się na założenie wsi lub kiedyś były wsiami, tak jest i w tym przypadku. Jeśli więc $w$ dokumencie podano liczbę wsi, to tyle ich zapewne wówczas było, niezależnie od liczby nazw. Dokładność przedstawionych informacji na temat majętności może być tylko taka, jak dokładność zachowanych dokumentów, nic ponadto.

Podobnie przedstawia się sprawa Ordynacji Ostrogskiej (s. 220). Dzieje tej ordynacji nie były przedmiotem specjalnych rozważań w pracy poświęconej Wiśniowieckim, istotny był jedynie kontekst jej przejęcia przez Teofilę z Zasławskich Wiśniowiecką i jej męża. Nie było tu więc mowy ani o zasadach organizacji ordynacji, ani o jej statucie, a jedynie w konkretnym przypadku powołano się na zapis statutu z roku 1624. Jak widać także i z przytoczeń Recenzenta, różne dokumenty dotyczące Ordynacji Ostrogskiej przedstawiają różne dane dotyczące jej wielkości, liczby miasteczek i wsi. Wiele zależało od tego, jak dokonywano zapisu, co potraktowano łącznie, a co oddzielnie, czy spis obejmował tylko zamieszkane, czy także niezamieszkane miejsca itd. Dlatego też kwestionowanie danych opartych na konkretnym materiale źródłowym w oparciu o inne źródła, pochodzące $z$ innego okresu lub inaczej zapisane, nie ma żadnych podstaw ani sensu.

Ciekawe, na jakiej podstawie Recenzent koryguje datę urodzenia Teofili Zasławskiej z roku 1654 na koniec 1655. Obok osobistego przekonania przydałaby się podstawa źródłowa takiego stwierdzenia. Również wątpliwości co do daty urodzenia Konstantego Krzysztofa Wiśniowieckiego nie bardzo są zrozumiałe wobec świadectwa jego własnego syna. Niewątpliwie też to Konstanty Krzysztof odziedziczył większą część należącej do dziadka włości wiśniowieckiej (czyli dóbr należących do klucza Wiśniowiec, nie należy ich mylić z innymi majętnościami wołyńskimi Wiśniowieckich) i część miasta Nowego Wiśniowca, które było podzielone i nie należało w całości do króla Michała, jak twierdzi Z. Anusik ${ }^{32}$. Oczywiście majętności Konstantego i Dymitra były porównywalne pod względem wielkości, jednak to głównie Dymitrowi przypadły najważniejsze centra tej gałęzi rodu Wiśniowieckich: Zbaraż i Załoźce. Niestety, dlaczego spis miejscowości, które otrzymał Konstanty Krzysztof w dziale spadku z bratem, podany w dokumencie in extenso, nie zgadza się z wiedzą Recenzenta, której źródła nie podał, nie potrafię wyjaśnić.

${ }^{32}$ Dokładny opis Wiśniowca, wraz z informacją jakie części należały do poszczególnych przedstawicieli rodu, znajduje się w dokumencie sprzedaży przez Aleksandrę z Wiśniowieckich Czartoryską części Wiśniowca Michałowi Wiśniowieckiemu. Centralnyj Deržavnyj Istoričeskij Archiv, Kiiv, Kremeneckij Ziemskij Sud, ks. 12 (1601 r.), dok. 42, k. 83 v-85, wpis z 02 VIII 1601. 
Sprawa pierwszego małżeństwa Franciszki Ludwiki jest wyjątkowo dobrze oświetlona źródłami. Mikołaj Tarło jeszcze w roku 1685 toczył proces z Konstantym Wiśniowieckim, niewątpliwie więc chyba nie prowadził go po śmierci.

Nieprawdą jest sugestia Zbigniewa Anusika, że Katarzyna Dolska po śmierci ojca była jedyną dziedziczką jego fortuny. Dziedzicem Jana Karola Dolskiego był wówczas syn jego i Anny Chodorowskiej - Krzysztof. Zmarł on trzy lata po śmierci ojca i dopiero wówczas, już jako żona Michała Wiśniowieckiego, Katarzyna została jedyną spadkobierczynią ojcowskiego majątku. O tym, że brat przyrodni Krzysztof przeżył ojca, napisał sam Janusz Wiśniowiecki, który niewątpliwie wiedział, jakie miał rodzeństwo i jak długo ono żyło ${ }^{33}$. Genealogowie z reguły nie odnotowują małych dzieci, nic dziwnego, że i w tym wypadku zmarły w wieku kilku lat Krzysztof Dolski nie został przez nich odnotowany.

Co do nabycia przez Annę Dolską praw do majątków zadnieprzańskich od spadkobierców królowej Eleonory, to może ekstrawagancja - ale fakt. Również sama księżna pisała o tym wyraźnie. Król Michał zapisał $\mathrm{w}$ testamencie wszystkie swe posiadłości znajdujące się wówczas poza granicami kraju małżonce i był to zapis na własność, a nie dożywocie. Eleonora jeszcze w roku 1678 próbowała je sprzedać za pośrednictwem Michała Kazimierza Paca za 300000 florenów, niewątpliwie więc, choć nie mogła z nich korzystać, zachowywała do nich prawo. Nie było żadnych przeciwwskazań, aby prawo to nie przeszło na jej dzieci z drugiego małżeństwa z Karolem Lotaryńskim.

Jest oczywiste, że w tego typu publikacji sprawa Mazepy musiała być przedstawiona w sposób uproszczony (s. 228), bo to temat sam w sobie na książkę, niemniej po raz kolejny przedstawiony przeze mnie pogląd został przez Recenzenta mocno zdeformowany. Nie twierdziłam i nie twierdzę, że to uczucie do Anny Dolskiej spowodowało przejście Iwana Mazepy na stronę Karola XII, wręcz przeciwnie, napisałam wyraźnie: Oczywiście fascynacja którejś ze stron, może nawet wzajemna, nie jest wykluczona, oboje byli jednak ludźmi zbyt dojrzałymi i zbyt świadomymi swych celów, by można było uznać ja za główny motor ich działań. Nie zgadzam się też z opinią Zbigniewa Anusika na temat Mazepy. Fakt, że współpracował on z carem Piotrem I, bynajmniej nie przekreśla jego autentycznych działań na rzecz samodzielności Ukrainy, o czym świadczy cała jego działalność, zarówno na polu administracyjnym, jak i przede wszystkim kulturalnym. Wykonywał on oczywiście rozkazy cara Piotra, ale przy tym robił swoje. Także jego tajne negocjacje z Leszczyńskim za pośrednictwem Anny Dolskiej zaczęły

${ }^{33}$ Biblioteka Jagiellońska, sygn. 3692, p. 46. 
się już w roku 1706, gdy jeszcze nie było mowy o jakimkolwiek jego zagrożeniu na Ukrainie i to jest tu najistotniejsze. A to, że się długo wahał, maskował i prowadził dwulicową grę, to oczywiste, ale zupełnie nie należy do tematu. Wypowiedź Recenzenta w sprawie Mazepy stwarza wrażenie, jakby nie wiedział o jego tajnych kontaktach z Polakami, które są sprawą dobrze znaną i opisaną.

Wbrew twierdzeniu Zbigniewa Anusika (s. 229), musiał należeć do Wiśniowieckich leżący na Podolu Jampol, a przynajmniej jakaś jego część. Występował on w spisach majętności zarówno Dymitra Wiśniowieckiego, jak i później w dziale spadku między jego wnuczkami: Wiktorią i Teofilą Leszczyńskimi. Nie może tu być żadnej pomyłki, bo w tym dokumencie występują wyraźnie dwa Jampole, jeden na Wołyniu, a drugi na Podolu.

Jak zwykle też zresztą określenie ",jeden z najbogatszych", dotyczące Janusza Wiśniowieckiego, Recenzent traktuje jak „najbogatszy”, podając jako przykład kilka nazwisk bogatszych rodzin magnackich (s. 229). Pomijając fakt, że Janusz Wiśniowiecki tak czy inaczej mieścił się niewątpliwie w grupie najbogatszych magnatów, zwłaszcza po swym małżeństwie z Teofilą Leszczyńska, nie można przecież porównywać rodzin i konkretnych osób.

Wyraźnym wypaczeniem mojego tekstu, który brzmiał: W lipcu 1705 roku pod wodza Stanistawa Chomentowskiego i Stanisława Denhoffa [Janusz Wiśniowiecki] wzią udział w niefortunnej wyprawie na stanisławowska Warszawe, rozbitej przez generała Magnusa Nierotha, jest następujący komentarz Recenzenta (s. 229): niefortunna wyprawa wojsk sasko-polskich na Warszawe, rozbita jakoby w lipcu "przez generała Magnusa Nierotha" (s. 372), zakończyła się w istocie zwycięska dla Szwedów bitwa stoczona w dniu 1 sierpnia 1705 r.

W taki oto sposób informacja o udziale Janusza Wiśniowieckiego w wyprawie na Warszawę w lipcu 1705 roku stała się błędną informacją o zwycięstwie Szwedów odniesionym 1 sierpnia.

Absolutnie nieprawdziwe jest twierdzenie Zbigniewa Anusika że $a b-$ solutnie nieprawdziwe jest twierdzenie Autorki, że Franciszka Urszula Radziwiłłowa założyła w 1739 r. manufakturę w Urzeczu produkujaca zwierciadła (s. 401). W rzeczywistości bowiem manufaktura ta została założona przez jej teściowa - Annę Katarzynę z Sanguszków, która konsekwentnie zabiegała o uprzemysłowienie dóbr radziwiłłowskich $i$ bardzo sprawnie nimi zarządzała (s. 232233). Anna Radziwiłłowa założyła w swych dobrach wiele manufaktur, w tym również manufakturę szklaną w Urzeczu, natomiast Franciszka Urszula, za zgodą świekry zresztą założyła tam manufakturę produkującą zwierciadła. Jeszcze w połowie XIX wieku pracowały tam obydwie manufaktury. Zachowany w Archiwum Radziwiłłowskim w AGAD materiał źródłowy wyraźnie wskazuje na założenie przez Franciszkę Urszulę 
manufaktury produkującej zwierciadła oraz jej osobisty zarząd, włącznie z rekrutacją chłopów z jej dóbr do pracy w tejże manufakturze ${ }^{34}$.

Nie ma też racji Recenzent, pisząc: kłopoty finansowe Franciszki i jej męża wynikaty też z faktu, że jej teściowa żelazna ręka trzymała dobra po Karolu Stanisławie Radziwille (s. 233). Świekra mogła trzymać majętności męża i nie oddać ich synowi, ale Franciszka musiała otrzymać należne jej zabezpieczenie, gwarantował to kontrakt ślubny. Zresztą w miejscu, do którego odnosi się powyższy tekst, była mowa o długach Franciszki, będących rezultatem spadku po przejęciu przez nią majętności ojcowskich, a nie o długach małżonków Radziwiłłów.

Recenzent nagminnie nie bierze pod uwagę faktu, że wszelkie wydarzenia polityczne $\mathrm{w}$ Europie $\mathrm{w}$ książce poświęconej Wiśniowieckim muszą być potraktowane wyłącznie z ich perspektywy. Tak więc na decyzję Michała Serwacego o powrocie do kraju w roku 1716 mogły mieć wpływ wypadki, które nastąpiły w latach 1713-1715. Wbrew sugestiom Zbigniewa Anusika (s. 236) nie ma tu żadnej sprzeczności. Była to cała seria wydarzeń, które spowodowały osłabienie szans Stanisława Leszczyńskiego. Oczywiście wierzę tu autorowi biografii Karola XII, że król szwedzki nie zamierzał rezygnować z pomocy dla osadzonego przez siebie króla Polski, jednak nie miał już realnych możliwości wsparcia go w odzyskaniu tronu i to stało się widoczne.

Wypowiedź Recenzenta (s. 237): Warto jednak uściślić stwierdzenie Ilony Czamańskiej, iż jego [Michała Serwacego Wiśniowieckiego] majątek oceniano

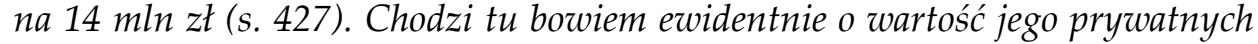
dóbr ziemskich, które przynosity roczne dochody w wysokości 700 tys. zł. Do tego $z$ pewnościq należałoby doliczyć jeszcze dochody z królewszczyzn oraz trudne do oszacowania ruchomości. Byt to bez watpienia majatek bardzo znaczny, ale z pewnościa nie największy w skali całej Rzeczypospolitej - ma się nijak do tekstu książki. Informacja na temat szacunku majątku Michała Serwacego na podanej przez Recenzenta stronie zapisana została bowiem w zupełnie innym kontekście, jedynie w nawiasie, jako ilustracja jego możliwości finansowych w związku z prowadzoną działalnością budowlaną. Nie mogło więc być tam mowy ani na temat tego, co wchodziło w skład szacowanego majątku, ani o wysokości rocznego dochodu, ani tym bardziej o miejscu zajmowanym przez Wiśniowieckiego pod względem majątkowym w skali Rzeczypospolitej.

Rzekomo nieprawdziwe dane podane przeze mnie na temat spadkobierców Michała Serwacego (s. 237) są w istocie krótszą wersją tego, co zaproponował dalej Recenzent. Ta krótka wersja w biogramie Michała Ser-

${ }^{34}$ AGAD, Archiwum Radziłłów, sygn. XI 155, p. 10 i in. 
wacego jest uzasadniona, bowiem bardziej szczegółowo sprawy schedy po nim omówione są w biogramach jego córek. Wykorzystywanie przez Recenzenta informacji znajdujących się $\mathrm{w}$ książce $\mathrm{w}$ innych miejscach i wykazywanie ich jako rzekomych braków jest bardzo częstym zabiegiem stosowanym $w$ tej recenzji. Podobny zarzut postawił Recenzent w odniesieniu do informacji zawartych $\mathrm{w}$ biogramie Elżbiety, pisząc: Córce $i$ jej mężowi przekazała Elżbieta wszystkie dobra, które spadty na nia po śmierci ojca. Nie jest jednak prawda, że od razu weszła ona w ich posiadanie (s. 443). Dożywocie na wszystkich swoich dobrach zapisał bowiem Michat Serwacy swojej trzeciej żonie - Tekli Róży z Radziwiłłów. Jego spadkobiercy nie zaakceptowali tego stanu rzeczy i rozpoczęli procesy sądowe $z$ wdowa po wojewodzie wileńskim. W ich wyniku odzyskali najpierw (w 1746 r.) dobra po Dolskich, a później stopniowo przejmowali sukcesje po Wiśniowieckich. Ostatnie dobra po Michale Serwacym przeszły jednak w posiadanie jego wnuków dopiero po śmierci Tekli z Radziwiłłów w 1747 r. (ostatecznego podziału spadku dokonano w 1749 r.).

Piszę o tych sprawach w biogramie Tekli Róży, natomiast w biogramie Elżbiety, na który powołuje się Recenzent, nie ma w ogóle mowy o tym, kiedy majętności zostały przejęte przez jej córkę, jest tylko mowa, że po śmierci ojca w roku 1744 Elżbieta została uprawniona do spadku po nim. Nie ma przy tym racji Recenzent, pisząc, że Tekla Róża zatrzymała wszystkie majętności po śmierci swego drugiego męża. Niemal natychmiast po pogrzebie Michała Serwacego została bowiem usunięta z Wiśniowca.

Nie ma też racji Zbigniew Anusik, twierdząc, że dobra Borklo w Holandii zostały przez Wiśniowieckich sprzedane, a cytowany przeze mnie dokument jest dokumentem sprzedaży (s. 240). Na temat dóbr Borklo, będących w posiadaniu Tekli Róży, zachowały się dość liczne źródła: archiwalia w Wilnie i Warszawie oraz dwa druki. Jeden z tych druków, niewielki (dwie kartki - może zdekompletowany), jest dość popularny w polskich bibliotekach, drugi natomiast, kilkudziesięciostronicowy, znany mi jest tylko w jednym egzemplarzu i został przeze mnie odnaleziony zupełnie przypadkowo, zszyty z innymi materiałami, w Bibliotece Uniwersyteckiej w Poznaniu ${ }^{35}$. Pozwolę sobie wyrazić wątpliwość, czy Szanowny Recenzent widział druk, na którego temat wypowiada się tak autorytarnie. A zawiera on sprawozdania z zarządu majętnościami za okres

${ }^{35}$ Pieces relatives aux differens entre son Altesse Madame la Princesse Wisniowieska née Princesse de Radziwit, à devant Epouse de son excellense Monseigneur le comte de Fleming, Feld-mareschal de Saxe etc. et Son Excellence Mr le Comte de Flodroff-Wartensleben Seigneur de Borculo, Leewen, Dorth, Lovuth et Stavenerse, b. m. i d. [1733?]. Tekst wszyty w: J. Ostrowski-Daneykowicz, Swada polska y łacińska, Lublin 1745. 
kilku lat, plenipotencje dla zarządzającego majątkiem hr. [Karla] FlodroffWartensleben, rozliczenia dochodów i wpłat do banku. Niewątpliwie różnica między dochodem wynoszącym 354888 florenów a dokonaną przez Flodroffa wpłatą 300000 florenów była przedmiotem sporu, powodem odsunięcia Flodroffa i mianowania nowego zarządcy. Zresztą Tekla Róża nie mogła sprzedać dóbr, których stan prawny nie był do końca uregulowany. Nie można też sprzedać i mieć zarazem, a księżna była posiadaczką tych dóbr do swej śmierci. Przejęła te majątki jako opiekunka swego synka z Flemingiem, po jego śmierci zachowała dożywotnio, majętności te znajdowały się w spisie pozostałych po niej dóbr, nie były jednak przedmiotem spadku po niej, lecz wróciły do rodziny Fleminga ${ }^{36}$.

Wypaczeniem mojego tekstu jest następująca interpretacja Recenzenta (s. 241):

Nieprawda jest, że dobra Brody (Brodcy) i Maksymowicze nad rzeka Berezyna, które znalazły sie już w posiadaniu protoplasty rodu - kniazia Michała Zbaraskiego-Wiśniowieckiego, przeszły następnie w posiadanie książat Sanguszków, od których jakoby odkupiła je wdowa po kniaziu Aleksandrze, Katarzyna ze Skorutów (s. 459). Z wcześniejszych wywodów Autorki wynika bowiem, że żona księcia Aleksandra wykupiła te dobra (najpewniej z zastawu) od Andrzeja Kopcia.

Tymczasem mój tekst na s. 459 brzmi następująco: Żona Michała [1] wniosła Horki, Brodcy i Maksimowicze nad rzeka Berezyna. Majętności te niedtugo jednak pozostawaty w rodzie. Odziedziczył je Fedor [4], który zapisat je swej drugiej małżonce Nastazji z Żylińskich, ta zaś wniosła je swemu drugiemu mężowi Aleksandrowi Sanguszce-Koszerskiemu. Prawdopodobnie też jakieś majętności wniosła matka Aleksandra [2]. Wiadomo, że kniaź ten posiadał Myszów, Jeżów i Ustiług w powiecie włodzimierskim, zakupił też Drywin i Czerników. Już po śmierci Aleksandra [2], jego małżonka, Katarzyna Skorutianka [2.1], zakupiła wraz z dziećmi kolejne majętności: Załuzie, dwór jakimowski, Brody i Maksymowicze.

Gdzież tu mowa o odkupieniu przez Katarzynę Skorutiankę majętności od Sanguszków? W istocie przecież nawet nie wiadomo, czy zakupione przez nią Brody i Maksymowicze to na pewno majętności tożsame z tymi, które posiadał Michał Zbaraski-Wiśniowiecki. A pomysł z wykupem z zastawu to już nie mój, tylko Recenzenta, w źródłach niczego nie ma na ten temat.

Przykłady zupełnego wypaczania myśli zawartych $\mathrm{w}$ monografii można by jeszcze mnożyć. Pomijam tu „łapanie za słówka” i swobodną

\footnotetext{
${ }^{36}$ AGAD, Archiwum Radziwiłłów, sygn. XI 130, Dokumenty spadkowe po Tekli Róży.
} 
interpretację zdań czy sformułowań wyrwanych z kontekstu.

Recenzja, mimo że robi wrażenie bardzo merytorycznej, w istocie w przeważającej mierze taką nie jest. Tytuł i styl recenzji sugeruja jakoby praca zawierała tak istotne braki, że trzeba ją pisać na nowo, w większości jednak poprawki i dopełnienia Recenzenta albo mają charakter "kosmetyczny", albo nie dotyczą bezpośrednio Wiśniowieckich, albo wręcz lansują anachroniczne teorie, które w świetle nowego materiału źródłowego muszą zostać poddane weryfikacji. Dodać do tego należy autorytarny i miejscami ironiczny ton wypowiedzi, a także sugestię posiadania przez Recenzenta jakiejkolwiek wiedzy na temat przygotowania merytorycznego autorki w odniesieniu do spraw, o których ona nie pisze. Zupełnie nonszalancko podchodzi Recenzent do nowego materiału źródłowego, zaprezentowanego $\mathrm{w}$ monografii, zachowując się tak, jakby materiał ten nie istniał lub też miejscami, jakby znał doskonale źródła dotychczas nieznane i trudno dostępne. Dodać do tego należy zupełnie dowolne manipulowanie tekstem i przypisywanie autorce poglądów odmiennych, a często nawet przeciwnych niż te, które zostały wyrażone w monografii. Wypada więc na koniec zaprosić Recenzenta i oczywiście wszystkich zainteresowanych Czytelników do rzetelnego przestudiowania monografii i zawartego w niej materiału źródłowego, przypominając jednocześnie o istnieniu pewnych dobrych obyczajów w nauce, które zdają się już, tak jak książęta Wiśniowieccy, przechodzić do historii.

\section{BIBLIOGRAFIA:}

Anusik Z., O książętach Wiśniowieckich i czasach, w których żyli. Suplement do monografii rodu, „Przegląd Nauk Historycznych”, 8, 2009, 2, s. 149-245; http://przeglad.uni.lodz.pl/ t/2009nr2/za.pdf (dostęp 10 XI 2015).

Anusik Z., Studia i szkice staropolskie, Łódź 2011, s. 586-682. Tu pod tytułem Książęta Wiśniowieccy na tle swoich czasów.

Chmielewska M., Sejm elekcyjny Michała Korybuta Wiśniowieckiego 1669 roku, Warszawa 2006.

Czamańska I., Jakub Basilicos Heraklides - droga wyzwolenia Grecji?, „Balcanica Posnaniensia. Acta et Studia" 1999, t. IX/X, s. 133-152.

Czamańska I., Miron Barnovschi i jego rodzina w relacjach z Polakami, [w:] Wielowiekowe bogactwo polsko-rumuńskich związków historycznych i kulturowych, Suceava 2014, s. 79-89.

Czamańska I., Wiśniowieccy. Monografia rodu, Wydawnictwo Poznańskie, Poznań 2007.

Czapliński W., Firlej Zbigniew, Polski Słownik Biograficzny, t. VII, Kraków 1938-1948, s. 17.

Golimaş A. H., Un domnitor. O epocă. Vremea lui Miron Barnovschi Moghilă, voievod al Moldovei, Bucureşti 1980.

Gorczak B., Katalog rękopisów Archiwum XX Sanguszków w Sławucie, w Sławucie 1902.

Rezachevici C., Cronologia domnilor din Țara Românească şi Moldova, a. 1324-1881, vol. 1, Bucureşti 2001. 
Stoicescu N., Dicționar al marilor dregători din Țara Românească şi Moldova. Sec. XIV-XVII, Bucureşti 1971.

Wolff J., Kniaziowie litewsko-ruscy, Warszawa 1895.

Нова историја српског народа, уредник Д. Т. Батаковић, Београд 2000.

Родословне таблице и грбови српских династија и властеле, Београд 1991.

Prof. dr hab. Ilona Czamańska - kierownik Zakładu Bałkanistyki Instytutu Historii Uniwersytetu im. Adama Mickiewicza w Poznaniu. Zajmuje się dziejami Europy Środkowej i Południowo-Wschodniej, w szczególności dziejami państw rumuńskich i ludności wołoskiej na całym obszarze jej zamieszkiwania, wzajemnymi relacjami Słowian Południowych i innych ludów bałkańskich z Imperium Osmańskim, polsko-bałkańskimi związkami kulturowymi, genealogicznymi i politycznymi. Opublikowała książki: Mołdawia $i$ Wołoszczyzna wobec Polski, Węgier $i$ Turcji w XIV i XV wieku (Poznań 1996), Drakula. Wampir, tyran czy bohater (Poznań 2003, 2 wyd. 2913), Wiśniowieccy. Monografia rodu (Poznań 2007) oraz Bitwa na Kosowym Polu 1389 (Poznań 2015, współautor Jan Leśny); wydawnictwa źródłowe: Miron Costin, Latopis Ziemi Mołdawskiej i inne utwory historyczne (Poznań 1998); Poselstwo Rafała Leszczyńskiego do Turcji w 1700 roku (Leszno 1998); Dokumenty klasztoru oo. kamedułów z Pożajścia w Państwowym Archiwum Historycznym w Tbilisi (Poznań 2012) oraz kilkadziesiąt artykułów naukowych. Wspólnie ze Zdzisławem Pentkiem zredagowała Vademecum bałkanisty (Poznań 2009). Od ponad dwudziestu lat jest głównym redaktorem czasopisma „Balcanica Posnaniensia. Acta et Studia”, a od 2003 r. przewodniczącą Komisji Bałkanistyki przy Oddziale PAN w Poznaniu, e-mail: czaman@amu.edu.pl 